\title{
ARTICLE
}

\section{Data Processing Approach for the Screening and Quantification of Pesticide Residues in Food Matrices for Early-Generation Gas Chromatography Time-of-Flight Mass Spectrometry}

\author{
Elena Hakme* $\triangle$ Susan Strange Herrmann (D) Mette Erecius Poulsen iD \\ Research Group for Analytical Food Chemistry, National Food Institute, Technical University of Denmark, \\ Kemitorvet Building 202, 2800 Kongens Lyngby, Denmark
}

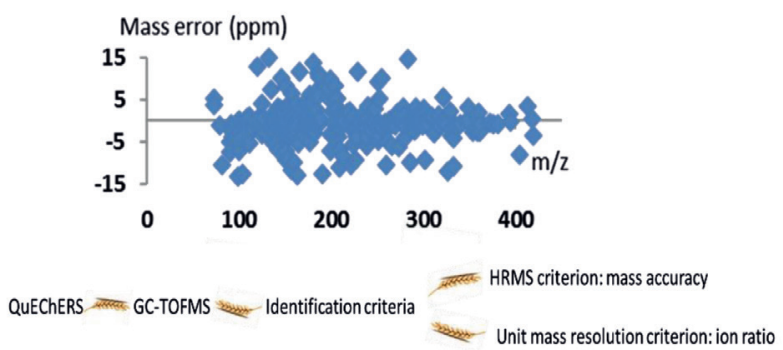

The application of high-resolution mass spectrometry (HRMS) in pesticide residue analysis is gaining popularity worldwide. Upgrading from early-generation gas chromatography time-of-flight mass spectrometry (GC-TOFMS) to higher resolution analysers is quite challenging, economically wise, for third countries' laboratories. Given the insufficient resolution of 12000 full width at half maximum (FWHM) or less offered by GC-TOFMS, meeting the HRMS identification requirements in some Analytical Quality Control guidelines may be challenging. This paper presents a useful approach for GC-TOFMS data processing for the screening and quantification of pesticide residues in cereals for laboratories disposing of that same equipment. The data obtained from spiking four types of cereals (wheat, rye, rice, and barley) at three different concentrations, $0.01,0.02$, and $0.1 \mathrm{mg} \mathrm{kg}^{-1}$ were evaluated with an "in-house" accurate-mass database of 102 pesticides, on the basis of two processing approaches. The data were first evaluated by considering the identification criteria in HRMS, which consists of the detection of two fragment ions of mass $\leq 5 \mathrm{ppm}$. The screening detection limits in that case were above $0.1 \mathrm{mg} \mathrm{kg}^{-1}$ for $25 \%$ of the compounds, owing to the high mass error (> 5ppm) obtained for some ions at low levels. The unsatisfactory results obtained were examined, and the data were re-evaluated by comparison with injected standards for identification (ion ratio). With this validated approach, the screening detection limit achieved for $85 \%$ of the compounds was $0.01 \mathrm{mg} \mathrm{kg}^{-1}$. Therefore, given the insufficient resolving power of the instrument for some pesticide/commodity pairs, the HRMS requirement of 12000 FWHM in TOFMS was demonstrated to be inapplicable. Consequently, we recommend applying the requirements for identification of unit mass resolution for these specific mass spectrometers, to ensure accurate screening and quantification.

Keywords: Cereals, pesticide residues, mass accuracy, resolving power, screening detection limit, data processing.

Cite: Hakme, E.; Herrmann, S. S.; Poulsen, M. E. Data processing approach for the screening and quantification of pesticide residues in food matrices for early-generation Gas Chromatography Time-of-Flight Mass Spectrometry. Braz. J. Anal. Chem., 2020, 7 (26), pp 51-77. doi: 10.30744/brjac.2179-3425.AR-36-2019

Received 4 November 2019, Revised 28 January 2020, Accepted 27 February 2020, Available online 31 March 2020. 


\section{INTRODUCTION}

The last true paradigm shift in the field of screening of pesticide residues in food was the shift from low-resolution mass spectrometry to high-resolution mass spectrometry (HRMS). HRMS enables broadspectrum analysis and the collection of full scan spectra with excellent mass accuracy and mass resolution. Because of the variety and complexity of food matrices and the different matrix/pesticide combinations that may be present, accurate mass information by HRMS is required for good selectivity and identification capabilities. High-resolution analysers can resolve the ions of interest from most possible interferences originating from both matrix ions and the chemical background in complex samples. However, Balogh [1] has noted that the sensitivity decreases as the mass resolving power is increased in ToF analyzers, and the argument for higher mass resolution does not become persuasive until the molecular weights being measured become significant. A higher resolution is theoretically a better option in the presence of coeluting isobaric compounds.

Numerous applications of HRMS in the literature indicate that this technique is highly suitable for screening pesticide residues in various food matrices [2,3]. Time-of-flight mass spectrometry (TOFMS) is a valuable approach that operates in full scan mode and can be combined with the development of an accurate-mass database for screening purposes; it has led to substantial improvements in food monitoring. GC-TOFMS is a powerful tool for screening pesticide residues in fruits and vegetables at a resolving power between 12500 and 18000 FWHM [4-7].

With the availability of GC-Orbitrap-MS, Mol et al. [8] have evaluated and demonstrated the efficiency of the full scan at a resolving power of 60000 FWHM in fruits and vegetables. The efficiency of a full scan with GC-Orbitrap-MS operated at a resolving power of 17500 FWHM for the analysis of pesticide residues in complex matrices, such as spices, has been described [9]. GC-Orbitrap-MS (resolving power: 100000 FWHM) is also effective in the analysis of pesticide residues in matrices that are difficult to analyse, such as wheat, maize and animal feed [10]. Thus, in the literature, a resolution ranging between 17500 and $100000 \mathrm{FWHM}$ has been found to allow screening of pesticide residues in various matrices. However, generally, the more complex a sample extract is to analyse, the higher the resolution power is needed [11] to avoid false positive detection. If resolving power is a limitation, the sample preparation may be optimized for complex samples to decrease the complexity.

Cereals are known as difficult/dirty dry matrices with a fat content varying from $2 \%$ (e.g., wheat) to $6.5 \%$ (e.g., oats) [12]. Sample preparation aims to decrease potential chemical interference and consequently the resolution requirements. However, even with the latest extraction methods, because of the development of multiresidue methods aiming to cover as many compounds as possible, a certain resolving power is necessary to distinguish isobaric compounds in difficult matrices such as cereals. Maximum residue limits (MRLs) for cereals have been established by the European Union (EU) in Directive 32/ EC for 353 pesticides, at values between 0.01 and $0.1 \mathrm{mg} \mathrm{kg}^{-1}$ for $94 \%$ of the compounds [13]. Therefore, low screening detection limits (SDLs) and limits of quantification (LOQs) are essential to fulfil the MRL requirements.

In this paper, the use of high-resolution full scan GC-TOFMS as a screening and quantification platform for pesticide residue analysis in cereals is described and evaluated. Compound identification was performed with an in-house updated high-resolution accurate mass database covering 102 pesticides. The 102 pesticides selected are not among the most frequently found pesticides (only 15 compounds are included in the European Union multi-annual monitoring program), hence the relevance of their use in testing the screening method. The European Union monitoring program and the European Union member states focus on the control of pesticides and the commodities that contribute most to the dietary intake of pesticides. Though new pesticides are authorised and illegal uses occur and it is therefore relevant to supplement the control programmes with a wide scope screening programme. GC-TOFMS operating in full scan mode at a resolving power of 12000 FWHM was evaluated with respect to mass resolution, mass accuracy, ion ratio, precision, and sensitivity. The main research question was whether a resolution of 12000 FWHM might be sufficient for accurate qualitative and quantitative screening of pesticide residues in cereals, in accordance with the EU screening requirements. Therefore, with spiking of four types of cereals at $0.01,0.02$, and $0.1 \mathrm{mg} \mathrm{kg}^{-1}$ and a QuEChERS extraction method, the SDLs were assessed 
according to SANTE guidelines, on the basis of accurate mass measurement of at least two representative ions [14]. The results were then re-evaluated by using additional requirements (standard and ion ratio). The validated method based on the second evaluation approach was finally applied in the screening of pesticide residues in 38 real samples of cereals and feeding stuffs.

\section{MATERIALS AND METHODS Chemical and reagents}

Pesticide standards (purity $>96 \%$ ) were purchased from Sigma-Aldrich or LGC Standards. Pesticide standard stock solutions of $1.000 \mathrm{mg} \mathrm{mL}-1$ were prepared in toluene and stored at $-18{ }^{\circ} \mathrm{C}$ in ampoules under an argon atmosphere. A standard mixture of $10 \mathrm{mg} \mathrm{mL}^{-1}$ was prepared from these stock solutions. Working standard solutions were prepared with standard-matched calibrations with cereal blank extract. The blank extracts were obtained from the extraction procedure described in the 'Extraction method' section. Acetonitrile (HPLC Grade 5) was purchased from Rathburn Chemicals (Walkerburn, UK). The buffer salt mixture was purchased from Thermo Scientific, and the clean-up sorbent Supel ${ }^{\mathrm{TM}} \mathrm{QuE}$ (EN) tubes were purchased from Supelco (Belleffonte, PA, USA).

\section{Extraction method}

The extraction procedure was performed with an acetate-buffered version of the QuEChERS method. The adopted method was previously validated by Herrmann et al. [15] with $25 \mathrm{mg}$ Primary Secondary Amine (PSA) per $\mathrm{mL}$ extract in the clean-up step for wheat, in accordance with EN 15662 [16]. Five grams of sample was weighed into a $50 \mathrm{~mL}$ centrifuge tube; $10 \mathrm{~mL}$ of cold deionized water and ceramic homogenizers were added; and the tubes were shaken vigorously so that the sample was soaked thoroughly. Afterward, $10 \mathrm{~mL}$ of acetonitrile was added, and the tubes were shaken vigorously by hand for $1 \mathrm{~min}$. A buffer-salt mixture from Thermo Scientific ${ }^{\mathrm{TM}}$, consisting of $4 \mathrm{~g}$ magnesium sulfate $\left(\mathrm{MgSO}_{4}\right), 1 \mathrm{~g}$ sodium chloride $(\mathrm{NaCl}), 1 \mathrm{~g}$ trisodium citrate dehydrate, and $0.5 \mathrm{~g}$ disodium hydrogencitrate sesquihydrate was added. The tubes were shaken with an automatic shaker (SPEX SamplePrep 2010 Geno/Grinder ${ }^{\circledR}$ ) for 1 min at $750 \mathrm{rpm}$ and then centrifuged for $10 \mathrm{~min}$ at 4500 rpm with a Heraeus ${ }^{\mathrm{TM}}$ Multifuge ${ }^{\mathrm{TM}} \mathrm{X} 3$ Centrifuge. Aliquots comprising $8 \mathrm{ml}$ of the acetonitrile extracts were transferred to $15 \mathrm{~mL}$ centrifuge tubes and stored in a freezer for a minimum of 1 hour at $-80^{\circ} \mathrm{C}$. The still-cold extracts were centrifuged in a cool centrifuge (at $5^{\circ} \mathrm{C}$ ) for $5 \mathrm{~min}$ to precipitate the low-soluble matrix co-extractives. Then $6 \mathrm{~mL}$ of acetonitrile extract was transferred to Supel ${ }^{\mathrm{TM}} \mathrm{QuE}$ tubes containing $150 \mathrm{mg}$ of PSA and $900 \mathrm{mg}$ of $\mathrm{MgSO}_{4}$. PSA allows the removal of fatty acids from the extract. The tubes were shaken in an automatic shaker for $1 \mathrm{~min}$ at $750 \mathrm{rpm}$ and then centrifuged for $5 \mathrm{~min}$ at room temperature $\left(20^{\circ} \mathrm{C}\right)$ at $4500 \mathrm{rpm}$. Subsequently, $4 \mathrm{~mL}$ of the cleaned-up extracts was transferred into $15 \mathrm{ml}$ centrifuge tubes, and $40 \mu \mathrm{l}$ of $5 \%$ formic acid solution in acetonitrile was added to each extract to adjust the $\mathrm{pH}$ for storage stability. The extracts were later diluted by a factor of 2 with acetonitrile $(0.25 \mathrm{~g}$ of sample/mL) to obtain the same matrix concentrations as those in the calibration standards, according to the in-house routine procedure for the quantitative methods.

\section{Equipment}

The samples were analysed with an Agilent 7200 Accurate-Mass Q-ToF-GC/MS, 7890A GC coupled to a PAL-GC automated Sampler 80.

For gas chromatographic separation, a 7890A gas chromatograph (Agilent Technologies) was used. The samples were injected in programmed temperature vaporizer (PTV) mode. The PTV enables the injection of solvents with high vapor expansion, in contrast to the split/splitless injection mode, thereby enabling the use of acetonitrile as injection solvent. Thus, solvent exchange involving exchanging the acetonitrile from the final QuEChERS extracts with, e.g., ethyl acetate was unnecessary. The injection volume was $5 \mu \mathrm{L}$, and the inlet temperature was $60^{\circ} \mathrm{C}$. The analytes were separated in two fused silica HP-5MSUI capillary columns with $15 \mathrm{~m} \times 250 \mu \mathrm{m}$ inner diameter and a film thickness of $0.25 \mu \mathrm{m}$ (Agilent). Helium (99.999\% purity) was used as a carrier gas with a flow of $1.2 \mathrm{~mL} \mathrm{~min}^{-1}$ in the first column 
and $1.4 \mathrm{~mL} \mathrm{~min}^{-1}$ in the second. The oven temperature program was as follows: $60{ }^{\circ} \mathrm{C}$ hold for $3 \mathrm{~min}$, increase to $180{ }^{\circ} \mathrm{C}$ at $30^{\circ} \mathrm{C} \mathrm{min}-1$, and then increase to $300^{\circ} \mathrm{C}$ at a rate of $5^{\circ} \mathrm{C} \mathrm{min}^{-1}$. The total run time was $31.8 \mathrm{~min}$, with four additional minutes for backflushing at $310^{\circ} \mathrm{C}$. The benefits of backflushing in capillary gas chromatography include better quality data and lower operating costs; it reduces the carryover of high boiling point compounds and it also helps to keep the electron ionization (EI) source clean resulting in less chemical background.

For the mass spectrometric analysis, a 7200 Accurate-Mass Q-ToF-GC/MS quadrupole time of flight (Q-ToF) mass spectrometer Agilent 7200 (Agilent Technologies) was used. The ion source operates in $\mathrm{El}$ mode and spectra were collected at $70 \mathrm{eV}$. The El emission value was set at $3.8 \mu \mathrm{A}$. The ion source temperature was set at $230{ }^{\circ} \mathrm{C}$, and the transfer line temperature was set at $300{ }^{\circ} \mathrm{C}$. The high-resolution mode of $4 \mathrm{GHz}(12000 \mathrm{FWHM})$ at which the TOFMS operated in full scan enabled higher confidence in analyte identification. Internal mass calibration with perfluorotributylamine was performed before each injection for improved accurate mass operation. An automatic stop of the sequence occurred when the mass error exceeded $5 \mathrm{ppm}$. Data acquisition was performed with GC-Q-ToF MassHunter Data Analysis at a mass range of 69-500 Da with an acquisition rate of 5 spectra/s. MS data were collected in centroid mode.

\section{Database}

An exact mass database was created and optimized for 102 compounds (Supplementary Material). For each pesticide, the chemical formula and molecular weight, as well as the formulas and exact masses of at least three selective/sensitive fragment ions were added.

When a new compound was to be included in the database, the ion fragmentation was first predicted with ChemDraw (up to five fragments). The percentage of fragment probability (mass accuracy) and the assigned formula were verified in Agilent Qualitative Software (Formula Calculator Tool) and ChemCalc software (Molecular Formula Finder tool). The exact mass of the fragment ions was calculated in Agilent Qualitative MassHunter software with the Mass calculator tool and on the Scientific Instrument Services, INC (SIS) website. The mass-to-charge ratio $(\mathrm{m} / \mathrm{z})$ corresponding to the molecular ion $\left(\mathrm{M}^{+}\right)$was obtained by subtraction of the electron's mass from the neutral mass (M). Even though the electron mass was very low $(0.00054858 \mathrm{Da})$, not subtracting it would have resulted in an initial theoretical mass error of $5 \mathrm{ppm}$ for ion masses of $m / z \leq 100$.

Later, a standard mix of the 102 pesticides was injected in the GC-TOFMS at different concentrations to create the database. The retention times were collected, and the three most selective/sensitive fragment ions in the total ion chromatogram were selected.

The database also included isotope clusters. Isotopes are variations in chemical elements with different numbers of neutrons and thus different masses: they have the same number of protons and electrons but a different number of neutrons. Their occurrence increases with increasing molecular weight. Chlorine, e.g., exists as a pair of isotopes, ${ }^{35} \mathrm{Cl}$ and ${ }^{37} \mathrm{Cl}$, in a near $3: 1$ ratio. $\mathrm{M}+2\left({ }^{37} \mathrm{Cl}\right)$ are elements with an isotope mass of $1.997050 \mathrm{Da}$ above that of the most abundant isotope $\left({ }^{35} \mathrm{Cl}\right)$. In some cases, and in accordance with selecting the most abundant ions for optimizing the method sensitivity, isotope clusters were included in the database to provide the most intense peaks. Bixafen (formula: $\mathrm{C}_{18} \mathrm{H}_{12} \mathrm{Cl}_{2} \mathrm{~F}_{3} \mathrm{~N}_{3} \mathrm{O}$, exact mass: 413.030951) is one such example. One of the three selective and sensitive ions of bixafen is an isotope cluster (formula: $\mathrm{C}_{18} \mathrm{H}_{12} \mathrm{Cl}(37 \mathrm{Cl}) \mathrm{F}_{3} \mathrm{~N}_{3} \mathrm{O}$; exact mass: 415.028001).

For sample screening, an automatic library search using the "Find compounds by formula option" in Agilent Qualitative Software is useful. The search can be filtered, selecting at least three fragment ions, a mass accuracy threshold of $\pm 5 \mathrm{ppm}$, a minimum peak intensity and a score of formula matching including isotopes (above 70\%). However, with this approach, the number of false positive findings is high. To decrease the number of incorrect hits, the results must be assessed manually, thus making data review time consuming [17]. This approach is not recommended for sample screening on GC-QTOF. Therefore, the optimized database that was first maintained as a Microsoft Excel spreadsheet was imported into Agilent MassHunter Quantitative software for rapid data review and sample screening. 


\section{Spiking procedure}

Four different types of cereals including blank samples of rice, rye, and barley, and two blanks of wheat were spiked at three concentrations of $0.01,0.02$, and $0.1 \mathrm{mg} \mathrm{kg}^{-1}$. The spiking experiment was performed with five replicates for each matrix at each concentration level. A total of 75 samples were injected for the validation of the screening and quantification method. Another 75 non-diluted extracts were injected to study the effect of the increased sensitivity on mass accuracy.

\section{Identification criteria}

Mass accuracy is generally reported as a ppm error and is calculated by taking the difference between the theoretical mass and the measured experimental mass, dividing by the theoretical mass, and then multiplying by $10^{6}$. According to SANTE guidelines [14], the requirements for identification with HRMS $(>10000)$ include a mass accuracy $\leq 5 \mathrm{ppm}$ for $\mathrm{m} / \mathrm{z}>200$, whereas for $\mathrm{m} / \mathrm{z}<200$, the mass accuracy must be $<1 \mathrm{mDa}$. For example, a fragment ion of $\mathrm{m} / \mathrm{z} 141.06988$ must have a mass error less than $\pm 7.1 \mathrm{ppm}$ $\left(0.001 / 141.06988 \times 10^{6}\right)$. Consequently, the mass error threshold is higher for lower $\mathrm{m} / \mathrm{z}$. However, for low mass range molecules and fragments, the probability of possible elemental composition is lower because there are fewer elements to combine. Consequently, a higher mass error can be accepted [18]. Moreover, regarding identification requirements, the signal to noise ratio must be $\geq 3$, and the analyte peaks of the fragment ions in the extracted ion chromatogram (EIC) must fully overlap.

\section{Method validation for screening}

The qualitative screening method was validated according to SANTE guidelines. The validation involved at least 20 samples. The SDL was set at the lower concentration for which a certain analyte could be identified in at least $95 \%$ of the samples.

\section{Method validation for quantification}

The quantification method was validated according to SANTE guidelines [14]. The analytical performance of the method was determined by evaluation of the linearity, the recoveries and repeatability, the LOQ, the inter-day and intra-day precision, and estimation of the expanded uncertainty of the entire method. The matrix effect was also assessed.

Recovery and repeatability in terms of relative standard deviation (RSD) were calculated with each matrix at the three concentrations in the five replicates. The inter-day precision of the method was evaluated at the concentrations of $0.01,0.02$, and $0.1 \mathrm{mg} \mathrm{kg}^{-1}$ and was obtained by performing the same spiking process for five consecutive days. The intra-day precision was obtained by measuring the analytes five times on the same day and was also estimated at the three concentrations. The uncertainty (u') was estimated by the sum of the bias component results (u'bias) and the recovery's uncertainty u'(Rw) as follow:

$$
\mathrm{u}^{\prime}=\mathrm{u}^{\prime}(\mathrm{bias})+\mathrm{u}^{\prime}(\mathrm{Rw}) \quad \text { where } \mathrm{u}^{\prime} \text { bias }=\sqrt{R M S^{\prime}(\text { bias })}
$$

The u'(bias) was estimated by calculation of the root mean square of the bias (RMS'bias) derived from the inter-day reproducibility. The u'(Cref) contributions could be included in the bias component. The $u^{\prime}(R w)$ was obtained from the standard deviation of recoveries obtained on the same day. The expanded uncertainty U' was expressed as $2 u^{\prime}$ and was required to be less than $50 \%$. The uncertainty was also estimated at the three concentrations. The assessment of the matrix effect was performed by comparison of the slopes obtained with the calibration curves of wheat, rice, and barley to the slope of the calibration curve obtained with rye, the supposed easiest matrix, by calculating the slopes' relative standard deviation. 


\section{Real samples}

The validated GC-TOFMS method was applied to 38 real samples of cereals and feeding stuffs sampled from the Danish market as part of the annual control program and corresponding to samples of wheat, barley, rye, basmati rice, jasmine rice, parboiled rice, white rice, red rice, pudding rice, rapeseed, linseed, sunflower seed, and hemp seed. Feeding stuffs have similar matrix profile than cereal samples, therefore it was relevant to analyse feeding stuff samples using the validated method of cereals.

\section{RESULTS AND DISCUSSION \\ Evaluation of screening detection limits}

First approach

First, the examination of the average mass accuracy of the 306 ions was conducted, after screening of 75 samples spiked at different concentrations. The average mass accuracy obtained from the 25 injections at the concentration of $0.1 \mathrm{mg} \mathrm{kg}^{-1}$ was below $\pm 5 \mathrm{ppm}$ for $88 \%$ of the fragment ions. In addition, $78 \%$ of the ions showed an average mass accuracy below $\pm 5 \mathrm{ppm}$ at $0.02 \mathrm{mg} \mathrm{kg}^{-1}$, and $72 \%$ of the ions showed an average mass accuracy below $\pm 5 \mathrm{ppm}$ at $0.01 \mathrm{mg} \mathrm{kg}^{-1}$. Overall, the average mass accuracy obtained at different concentrations for all the compounds indicated that the probability of mass error was higher at low concentrations $\left(0.01 \mathrm{mg} \mathrm{kg}^{-1}\right)$ and low $\mathrm{m} / \mathrm{z}(<200)$.

However, according to SANTE guidelines, to calculate the SDL for accurate screening, the results must be evaluated for each compound, as described in the 'Identification criteria' section. Figure 1 shows the percentage of compounds that achieved an SDL of $0.01,0.02,0.1$, and above $0.1 \mathrm{mg} \mathrm{kg}^{-1}$. The SDL was $0.01 \mathrm{mg} \mathrm{kg}^{-1}$ for only $16 \%$ of the compounds, $0.02 \mathrm{mg} \mathrm{kg}^{-1}$ for $27 \%$ of the compounds, and $0.1 \mathrm{mg} \mathrm{kg}^{-1}$ for $37 \%$ of the compounds. No SDL could be established for $25 \%$ of the compounds. These compounds were not validated, but an SDL above $0.1 \mathrm{mg} \mathrm{kg}^{-1}$ was associated with those compounds.

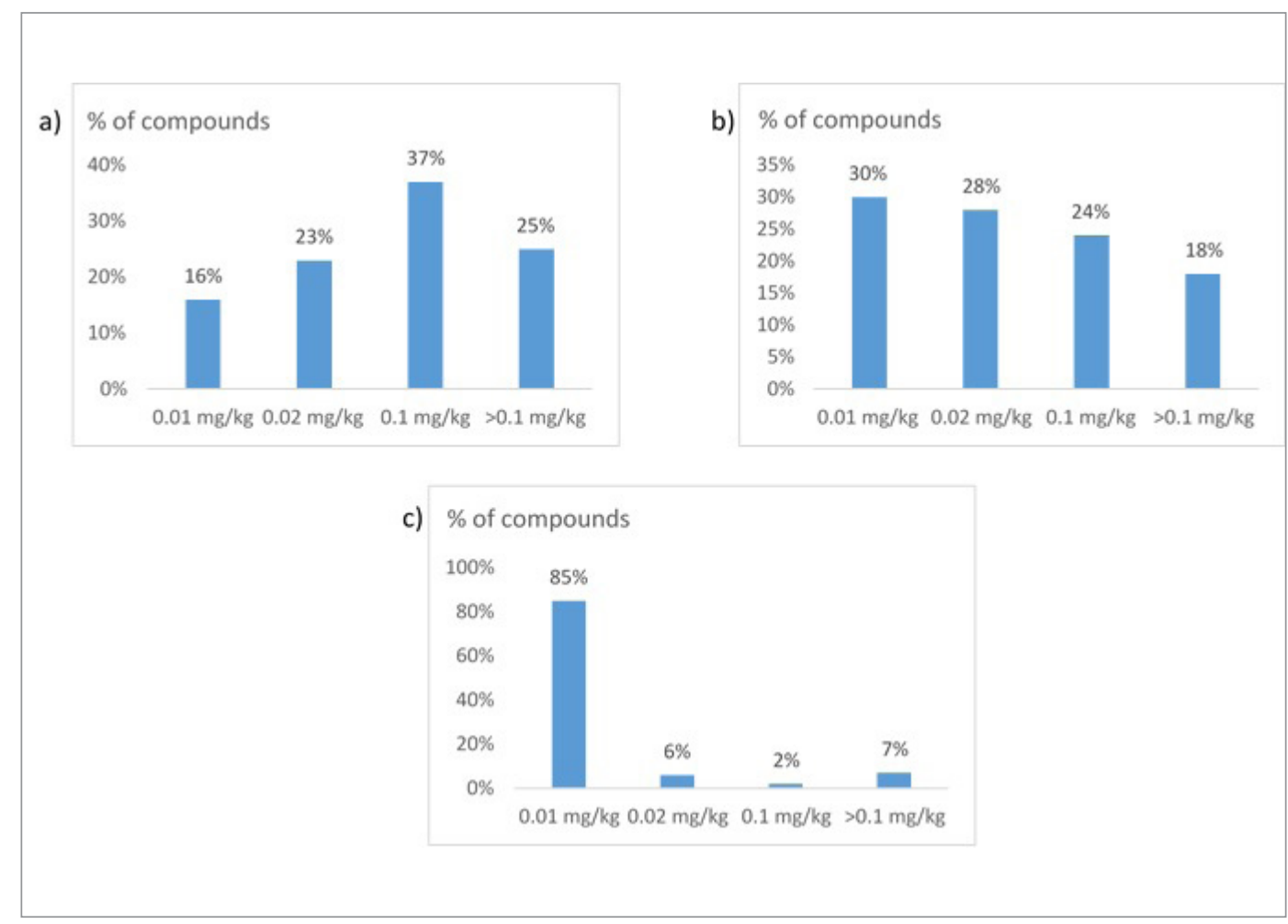

Figure 1. SDLs in $\mathrm{mg} \mathrm{kg}^{-1}$ of the 102 compounds obtained with a) diluted extracts, b) non-diluted extracts, c) non-diluted extracts and considering the standards. 
Some of the compounds were not well extracted with acetonitrile and required a single residue method to obtain satisfactory results; these compounds included cycloxidim (log P: 1.36), chloridazon (log P: 1.19), 8-hydroxyquinoline ( $\log P: 1.915)$, and cyromazine $(\log P: 0.069)$. Dicrotofos $(\log P:-0.5)$ and amidosulfuron ( $\log P:-1.56)$ were also not well extracted with acetonitrile. Other compounds showed poor extraction efficiency, such as dimoxystrobin (log P: 2.2), flumioxazin (log P: 2.55), and tralkoxydim (log P: 2.1). Ametoctradin (pKa: 2.78) is a strong acid and may be retrieved in its ionized form, and therefore is better extracted with water or other water-miscible solvents. The other compounds exhibited low sensitivity. The small molecules carvone $\left(\mathrm{C}_{10} \mathrm{H}_{14} \mathrm{O}\right.$, exact mass: 150.104465) and fuberidazole $\left(\mathrm{C}_{11} \mathrm{H}_{8} \mathrm{~N}_{2} \mathrm{O}\right.$, exact mass: 184.063663), having small fragments, showed very low sensitivity, in agreement with findings from Ramanathan et al. [19] who have shown that a mass resolution of $12000 \mathrm{FWHM}$ is insufficient for detecting small molecules at low concentrations, owing to interference from endogenous compounds. The high SDL obtained for some compounds was associated with the four different matrices examined in this study. A major matrix peak was observed in the total ion chromatogram between 15 and 21 min with rice matrix. The matrix peak was generated by the high amounts of fatty acids in rice. In the 15-21 min time segment, a high number of pesticides also eluted.

In light of the data obtained, and given that low sensitivity was associated with the diluted samples, we assessed the mass accuracy without sample dilution. The spiked samples were injected without final dilution in the vial $(0.5 \mathrm{~g} \mathrm{sample} / \mathrm{mL})$. The SDLs obtained were $0.01 \mathrm{mg} \mathrm{kg}^{-1}$ for $30 \%$ of the compounds, $0.02 \mathrm{mg} \mathrm{kg}^{-1}$ for $28 \%$ of the compounds, and $0.1 \mathrm{mg} \mathrm{kg}^{-1}$ for $24 \%$ of the compounds. Moreover, $18 \%$ of the compounds showed an SDL above $0.1 \mathrm{mg} \mathrm{kg}^{-1}$ (Figure 1). Lower SDLs were obtained without the final dilution; however, using $0.5 \mathrm{~g}$ of sample $/ \mathrm{mL}$ rather than $0.25 \mathrm{~g}$ of sample $/ \mathrm{mL}$ would also increase the amount of matrix introduced into the instrument (liner, column, and ion source) and more maintenance would be required. Another approach to increase sensitivity is increasing the injection volume. The PTV injector allows use of high injection volumes [20]. However, an increase in sensitivity will not necessarily be accompanied by an increase in mass accuracy.

The SDLs were re-evaluated by considering a mass accuracy threshold of $10 \mathrm{ppm}$, in accordance with the US-FDA guidelines [21]. More satisfactory results in this case were obtained: $50 \%$ of the compounds showed an SDL of $0.01 \mathrm{mg} \mathrm{kg}^{-1}, 22 \%$ of the compounds showed an SDL of $0.02 \mathrm{mg} \mathrm{kg}^{-1}$, and $16 \%$ of the compounds showed an SDL of $0.1 \mathrm{mg} \mathrm{kg}^{-1}$.

Those results prompt the question of whether a resolving power of $4 \mathrm{GHz}, 12000 \mathrm{FWHM}$, might be sufficient for screening pesticides at low concentrations in difficult matrices as cereals, without the use of any standard.

\section{Second approach}

HRMS instruments were expected to allow the identification of compounds without the use of standards, by relying only on the mass accuracy of two fragment ions. However, given the poor results obtained with the first approach, even though three ions were assessed, the data were re-evaluated with identification criteria commonly applied to unit mass data [14]. For unit mass spectrometry, using certified standards and comparing the ion ratios obtained for a sample with that of a standard is a key requirement for identification [14]. Thus, identification is inadequate without the use of standards. Fortunately, in simultaneous screening and quantification studies, standards were also injected, thus enabling the ion ratios to be used for identification. When this second approach was applied, $85 \%$ of the compounds achieved an SDL of 0.01 $\mathrm{mg} \mathrm{kg}^{-1}, 6 \%$ of the compounds had an SDL of $0.02 \mathrm{mg} \mathrm{kg}^{-1}$. Only $2 \%$ of the compounds showed an SDL of $0.1 \mathrm{mg} \mathrm{kg}^{-1}$, and $7 \%$ of the compounds had an SDL above $0.1 \mathrm{mg} \mathrm{kg}^{-1}$ (Figure 1).

To improve understanding the differing results obtained with the two approaches, the correlation between the two identification criteria used was studied: the mass accuracy (first approach) and the ion ratio (second approach). Figure 2 provides a summary of the percentage of compounds that met the mass accuracy requirement ( $\pm 5 \mathrm{ppm}$ or $<1 \mathrm{mDa}$ compared with the database) and/or the requirement to ion ratio $( \pm 30 \%$ of standard) for identification. 


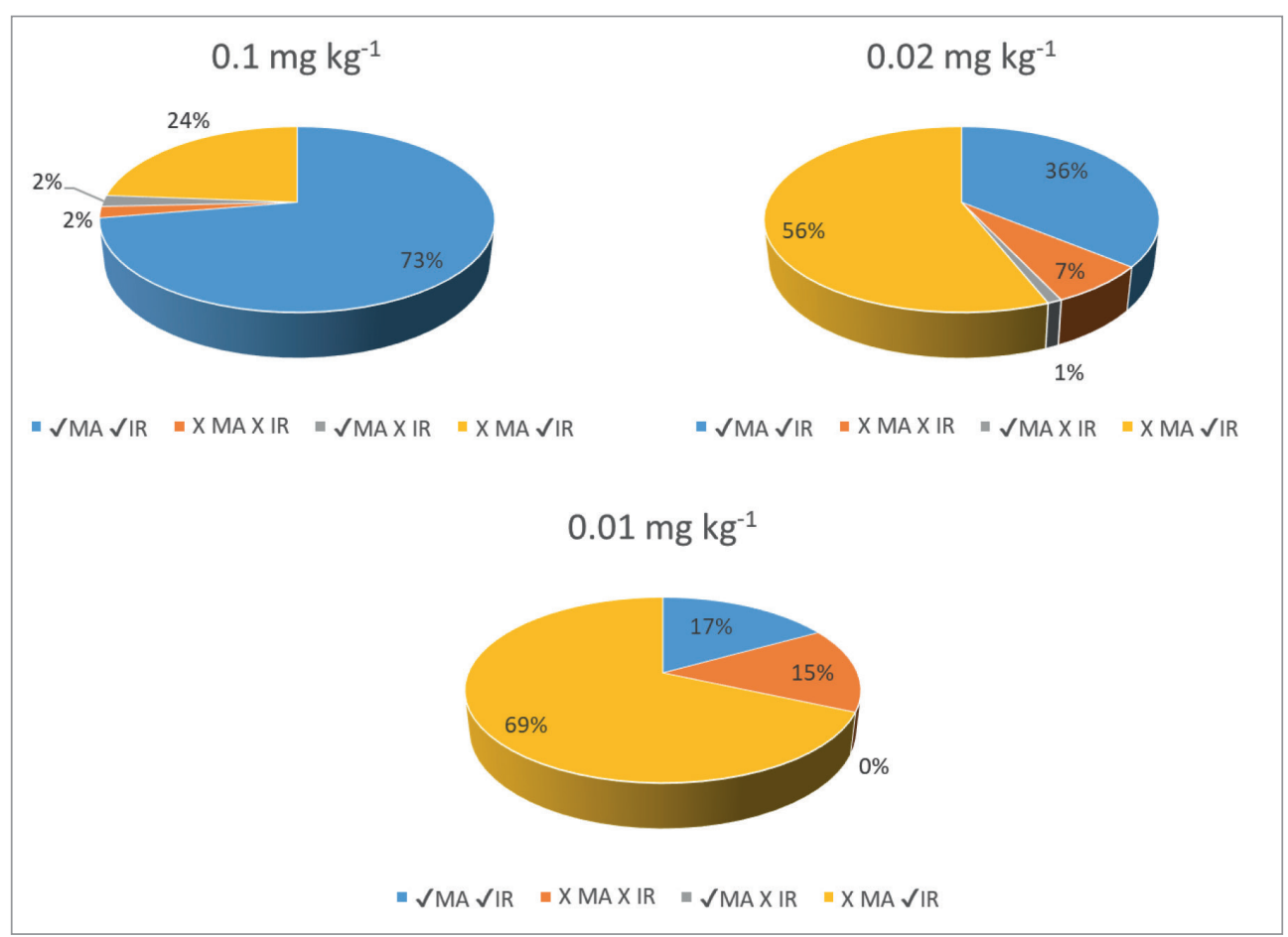

Figure 2. Correlation between mass accuracy and ion ratio at $0.1,0.02$ and $0.01 \mathrm{mg} \mathrm{kg}^{-1}$ (blue: percentage of compounds for which fragment ions have fulfilled both mass accuracy and ion ratio criteria. Orange: percentage of compounds that did not fulfill both ion ratio and mass accuracy criteria. Grey: percentage of compounds that have fulfilled the mass accuracy criterion but failed the ion ratio criterion. Yellow: percentage of compounds that have failed the mass accuracy criterion but have met the ion ratio criterion).

At $0.1 \mathrm{mg} \mathrm{kg}^{-1}, 75 \%$ of the compounds showed a positive correlation between the ion ratio and mass accuracy; when the mass accuracy criterion is met, so did the ion ratio results, and when the mass accuracy did not meet the criterion for peak identification, so did the ion ratio results. Therefore, peak identification based on mass accuracy was completely acceptable in that case, without the use of the ion ratio criterion (use of standards), because the two criteria gave the same indication. At $0.02 \mathrm{mg} \mathrm{kg}^{-1}$, $43 \%$ of the compounds showed a good correlation between mass accuracy and ion ratio. At $0.01 \mathrm{mg} \mathrm{kg}^{-1}$, the percentage of compounds was even lower: only $32 \%$ of the compounds showed a good correlation between mass accuracy and ion ratio. Therefore, the criterion of mass accuracy at low concentrations was insufficient in the last cases for compound identification.

At all the concentrations studied, a mass accuracy less than $5 \mathrm{ppm}$ was accompanied by an ion ratio less than $30 \%$, but not vice versa. At $0.1 \mathrm{mg} \mathrm{kg}^{-1}, 24 \%$ of the compounds showed high mass error (>5 ppm) but acceptable ion ratio (<30\%). At 0.02 and $0.01 \mathrm{mg} \mathrm{kg}^{-1}$, approximately $56 \%$ and $69 \%$ of the compounds, respectively, showed good ion ratio but low mass accuracy (above $5 \mathrm{ppm}$ or $1 \mathrm{mDa}$ ). These compounds met not only the ion ratio criterion but also the signal to noise ratio criterion, and the fragment ions were fully overlapping in the EIC. In the EIC of carfentrazone-ethyl and fenoxaprop-p-ethyl (Figure 3 ), carfentrazone-ethyl showed a good ion ratio and good mass accuracy for both qualifiers. Fenoxapropethyl showed a good ion ratio, but a high mass error was observed with both qualifiers. Ignoring these compounds because of their low mass accuracy might have resulted in false positive detection.

Therefore, at high concentrations, the first approach relying solely on mass accuracy was applicable. However, at low concentrations, the use of standards and the evaluation of ion ratio was found to be an applicable identification criterion. Relying only on mass accuracy resulted in many false positives. 


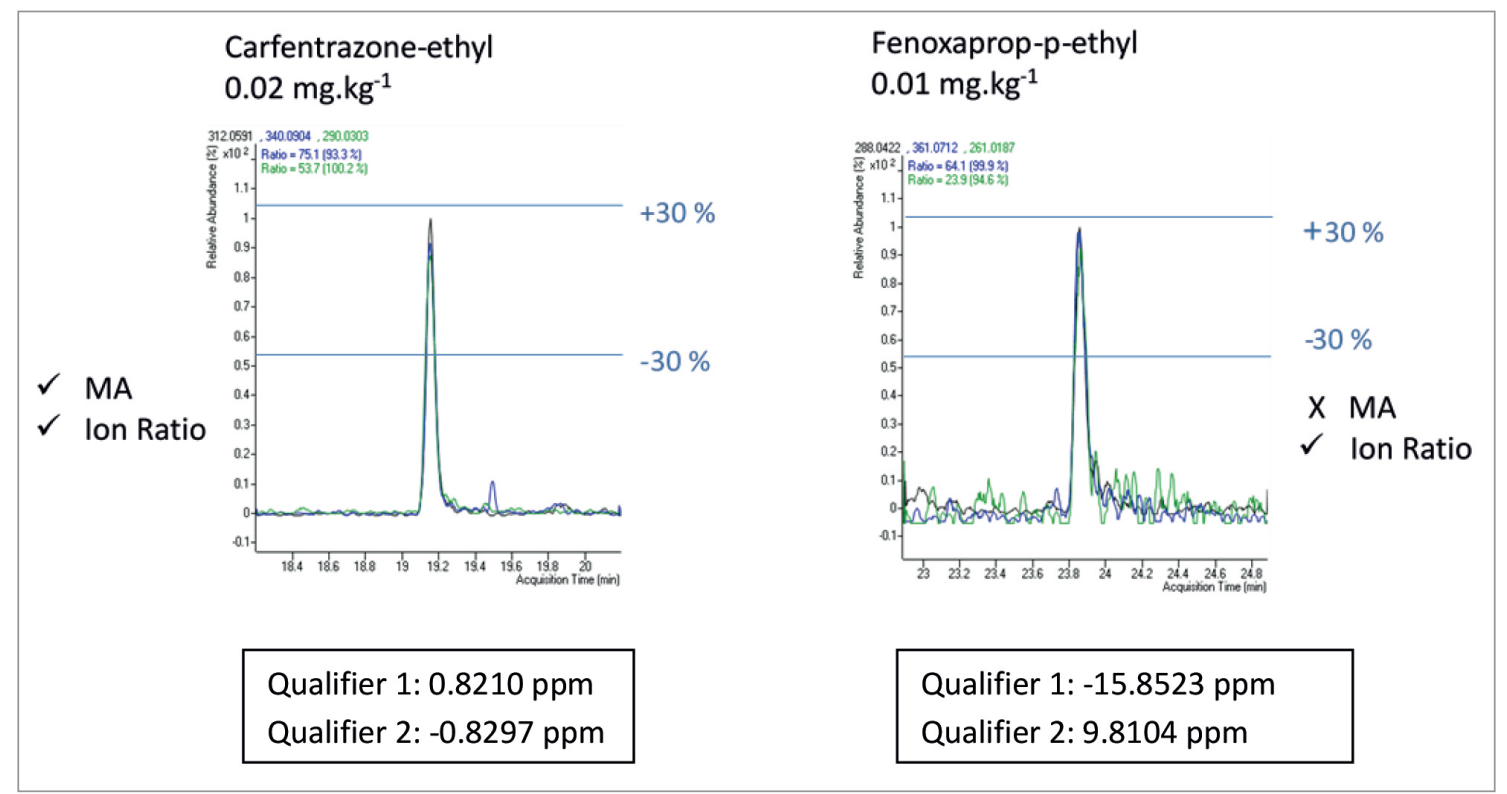

Figure 3. The extracted ion chromatograms of the two qualifiers of carfentrazone-ethyl and fenoxaprop-p-ethyl; ion ratio and mass accuracy.

The question was addressed again about how much resolution is needed to reach low detection limits with high accuracy. Regarding the identification criteria for screening pesticide residues in cereals at a resolving power of $12000 \mathrm{FWHM}$, the use of standards remains the most important tool for identification. With the availability of different HRMS with different resolving power, the identification requirements cannot be generalised. The limitations of equipment offering a resolution of $12000 \mathrm{FWHH}$ or less must be considered when analysing pesticide residues in difficult matrices.

The EU MRLs in force for the studied compounds in cereals vary from 0.01 up to $0.1 \mathrm{mg} \mathrm{kg}^{-1}$. Among the 102 compounds, 60 compounds had established EU MRLs. Using the extraction procedure described above and applying the first approach, SDLs equal to or below the corresponding EU MRLs were achieved for only $35 \%$ of the compounds. When the dilution step was omitted, $47 \%$ of the compounds fulfilled the $M R L$ requirements. If the ion ratio was considered along with the mass accuracy, i.e., the second approach was applied, $90 \%$ of the compounds were suitable for MRL compliance check. Table I lists the SDLs obtained by the application of both the first and the second approach along with the MRLs in force for each compound.

Table I. The SDLs achieved with $0.25 \mathrm{~g}$ sample $/ \mathrm{mL}$ of extract and with 0.5 sample $/ \mathrm{mL}$ of extract considering the identification requirements of the SANTE guidelines (Mass accuracy (MA), S/N, peaks overlapping), and the SDLs obtained with $0.25 \mathrm{~g}$ of sample $/ \mathrm{mL}$ by considering the ion ratio $(\mathrm{IR})$ criteria, and the EU MRLs established for cereals.

\begin{tabular}{|c|c|c|c|c|c|}
\hline & \multirow[b]{3}{*}{ Compounds } & \multirow[b]{3}{*}{$\begin{array}{c}\text { MRLs } \\
\left(\mathrm{mg} \mathrm{kg}^{-1}\right)\end{array}$} & \multirow{2}{*}{\multicolumn{3}{|c|}{ SDL (mg kg-1) }} \\
\hline & & & & & \\
\hline & & & $\begin{array}{c}\text { SDL } \\
(0.25 \mathrm{~g} \mathrm{sample} / \mathrm{mL})+\mathrm{MA}\end{array}$ & $\begin{array}{c}\text { SDL } \\
(0.5 \mathrm{~g} \text { sample } / \mathrm{mL})+\mathrm{MA}\end{array}$ & $\begin{array}{c}\text { SDL } \\
(0.25 \mathrm{~g} \mathrm{sample} / \mathrm{mL})+\mathrm{MA}+\mathrm{IR}\end{array}$ \\
\hline 1 & 1-Naphthylacetic acid & 0.06 & 0.02 & 0.02 & 0.01 \\
\hline 2 & 1-Naphtylacetamide & 0.06 & 0.1 & 0.02 & 0.01 \\
\hline 3 & 8-Hydroxyquinoline & 0.01 & $>0.1$ & $>0.1$ & $>0.1$ \\
\hline 4 & Acetochlor & 0.01 & 0.02 & 0.02 & 0.01 \\
\hline 5 & Aclonifen & 0.01 & 0.1 & 0.1 & 0.01 \\
\hline 6 & Ametoctradin & 0.05 & $>0.1$ & $>0.1$ & 0.02 \\
\hline
\end{tabular}


Table I. The SDLs achieved with $0.25 \mathrm{~g}$ sample $/ \mathrm{mL}$ of extract and with 0.5 sample $/ \mathrm{mL}$ of extract considering the identification requirements of the SANTE guidelines (Mass accuracy (MA), S/N, peaks overlapping), and the SDLs obtained with $0.25 \mathrm{~g}$ of sample/mL by considering the ion ratio (IR) criteria, and the EU MRLs established for cereals. (Cont.)

\begin{tabular}{|c|c|c|c|c|c|}
\hline & \multirow[b]{2}{*}{ Compounds } & \multirow[b]{2}{*}{$\begin{array}{c}\text { MRLs } \\
\left(\mathrm{mg} \mathrm{kg}^{-1}\right)\end{array}$} & \multicolumn{3}{|c|}{ SDL $\left(\mathrm{mg} \mathrm{kg}^{-1}\right)$} \\
\hline & & & $\begin{array}{c}\mathrm{SDL} \\
\text { (0.25 g sample } / \mathrm{mL})+\mathrm{MA}\end{array}$ & $\begin{array}{c}\mathrm{SDL} \\
(0.5 \mathrm{~g} \text { sample } / \mathrm{mL})+\mathrm{MA}\end{array}$ & $\begin{array}{c}\mathrm{SDL} \\
(0.25 \mathrm{~g} \mathrm{sample} / \mathrm{mL})+\mathrm{MA}+\mathrm{IR}\end{array}$ \\
\hline 7 & Amidosulfuron & 0.01 & $>0.1$ & $>0.1$ & 0.01 \\
\hline 8 & Amisulbrom & 0.01 & $>0.1$ & $>0.1$ & 0.01 \\
\hline 9 & Anthraquinone & 0.01 & $>0.1$ & $>0.1$ & 0.01 \\
\hline 10 & Benalaxyl & 0.05 & 0.02 & 0.02 & 0.01 \\
\hline 11 & Benfluralin & 0.02 & 0.02 & 0.01 & 0.01 \\
\hline 12 & Biphenyl & 0.01 & 0.01 & 0.01 & 0.01 \\
\hline 13 & Bixafen & & 0.1 & 0.1 & 0.01 \\
\hline 14 & Butralin & 0.01 & 0.1 & 0.02 & 0.01 \\
\hline 15 & Carbophenothion & & 0.1 & 0.02 & 0.01 \\
\hline 16 & Carfentrazone-ethyl & 0.05 & 0.1 & 0.02 & 0.01 \\
\hline 17 & Carvone & & $>0.1$ & $>0.1$ & $>0.1$ \\
\hline 18 & Chlorantraniliprole & & $>0.1$ & $>0.1$ & 0.01 \\
\hline 19 & Chloridazon & 0.1 & $>0.1$ & $>0.1$ & $>0.1$ \\
\hline 20 & Chloropropylate & & 0.02 & 0.01 & 0.01 \\
\hline 21 & Chlorthal-dimethyl & 0.01 & 0.1 & 0.02 & 0.01 \\
\hline 22 & Cinidon-ethyl & 0.05 & $>0.1$ & $>0.1$ & 0.01 \\
\hline 23 & Clodinafop-propargyl & 0.02 & $>0.1$ & 0.1 & 0.01 \\
\hline 24 & Cycloxydim & & $>0.1$ & $>0.1$ & $>0.1$ \\
\hline 25 & Cyflufenamid & & 0.1 & 0.01 & 0.01 \\
\hline 26 & Cyromazine & 0.05 & $>0.1$ & $>0.1$ & $>0.1$ \\
\hline 27 & Dialifos & & $>0.1$ & $>0.1$ & 0.1 \\
\hline 28 & Dichlobenil & 0.01 & 0.01 & 0.01 & 0.01 \\
\hline 29 & Dichlofenthion & & 0.02 & 0.01 & 0.01 \\
\hline 30 & Dicrotofos & & $>0.1$ & $>0.1$ & 0.01 \\
\hline 31 & Diflufenican & & 0.02 & 0.01 & 0.01 \\
\hline 32 & Dimetachlor & 0.02 & 0.02 & 0.02 & 0.01 \\
\hline 33 & Dimethenamid & 0.01 & 0.01 & 0.01 & 0.01 \\
\hline 34 & Dimoxystrobin & & $>0.1$ & $>0.1$ & 0.02 \\
\hline 35 & Diniconazole & 0.01 & 0.02 & 0.01 & 0.01 \\
\hline 36 & Dioxathion & 0.01 & $>0.1$ & $>0.1$ & 0.01 \\
\hline 37 & Ethalfluralin & 0.01 & 0.1 & 0.02 & 0.01 \\
\hline 38 & Ethofumesate & 0.03 & 0.01 & 0.01 & 0.01 \\
\hline 39 & Etoxazole & 0.01 & 0.1 & 0.1 & 0.01 \\
\hline 40 & Etridiazole & 0.05 & 0.1 & 0.02 & 0.01 \\
\hline 41 & Etrimfos & & 0.1 & 0.1 & $>0.1$ \\
\hline 42 & Famoxadone & & 0.1 & 0.1 & 0.01 \\
\hline 43 & Fenchlorphos & 0.01 & 0.01 & 0.01 & 0.01 \\
\hline
\end{tabular}


Table I. The SDLs achieved with $0.25 \mathrm{~g}$ sample $/ \mathrm{mL}$ of extract and with 0.5 sample $/ \mathrm{mL}$ of extract considering the identification requirements of the SANTE guidelines (Mass accuracy (MA), S/N, peaks overlapping), and the SDLs obtained with $0.25 \mathrm{~g}$ of sample/mL by considering the ion ratio (IR) criteria, and the EU MRLs established for cereals. (Cont.) 
Table I. The SDLs achieved with $0.25 \mathrm{~g}$ sample $/ \mathrm{mL}$ of extract and with 0.5 sample $/ \mathrm{mL}$ of extract considering the identification requirements of the SANTE guidelines (Mass accuracy (MA), S/N, peaks overlapping), and the SDLs obtained with $0.25 \mathrm{~g}$ of sample/mL by considering the ion ratio (IR) criteria, and the EU MRLs established for cereals. (Cont.)

\begin{tabular}{|c|c|c|c|c|c|}
\hline & \multirow[b]{2}{*}{ Compounds } & \multirow[b]{2}{*}{$\begin{array}{c}\text { MRLs } \\
\left(\mathrm{mg} \mathrm{kg}^{-1}\right)\end{array}$} & \multicolumn{3}{|c|}{ SDL (mg kg-1) } \\
\hline & & & $\begin{array}{c}\mathrm{SDL} \\
(0.25 \mathrm{~g} \text { sample } / \mathrm{mL})+\mathrm{MA}\end{array}$ & $\begin{array}{c}\mathrm{SDL} \\
\text { (0.5 g sample } / \mathrm{mL})+\mathrm{MA}\end{array}$ & $\begin{array}{c}\mathrm{SDL} \\
(0.25 \mathrm{~g} \text { sample } / \mathrm{mL})+\mathrm{MA}+\mathrm{IR}\end{array}$ \\
\hline 81 & Picolinafen & & 0.02 & 0.01 & 0.01 \\
\hline 82 & Picoxystrobin & & 0.02 & 0.01 & 0.01 \\
\hline 83 & Piperonylbutoxide & & 0.1 & 0.01 & 0.01 \\
\hline 84 & Pirimiphos-ethyl & & 0.02 & 0.02 & 0.01 \\
\hline 85 & Propachlor & 0.02 & 0.1 & 0.02 & 0.01 \\
\hline 86 & Propanil & 0.01 & 0.1 & 0.02 & 0.01 \\
\hline 87 & Proquinazid & 0.02 & 0.02 & 0.02 & 0.01 \\
\hline 88 & Pyraclofos & & 0.1 & 0.1 & 0.01 \\
\hline 89 & Pyridalyl & 0.01 & 0.1 & 0.02 & 0.01 \\
\hline 90 & Quinalphos & 0.01 & 0.1 & 0.1 & 0.01 \\
\hline 91 & Quintozene & 0.02 & 0.1 & 0.1 & 0.01 \\
\hline 92 & Siafluofen & & 0.02 & 0.01 & 0.01 \\
\hline 93 & Spiromesifen & 0.02 & 0.02 & 0.01 & 0.01 \\
\hline 94 & Sulfotep & & 0.1 & 0.1 & 0.01 \\
\hline 95 & Terbuthylazine & & $>0.1$ & 0.1 & 0.01 \\
\hline 96 & Tetrachlorvinphos & & 0.1 & 0.02 & 0.01 \\
\hline 97 & Tetrasul & & 0.1 & 0.02 & 0.01 \\
\hline 98 & Thiobencarb & 0.01 & 0.01 & 0.01 & 0.01 \\
\hline 99 & Tralkoxydim & 0.01 & $>0.1$ & $>0.1$ & 0.1 \\
\hline 100 & Tralomethrin & & $>0.1$ & $>0.1$ & 0.01 \\
\hline 101 & Trichloronate & & 0.02 & 0.01 & $>0.1$ \\
\hline 102 & Triflumizole & 0.1 & 0.1 & 0.02 & 0.01 \\
\hline
\end{tabular}

\section{Method validation for quantification}

Recoveries and repeatability

At $0.01 \mathrm{mg} \mathrm{kg}^{-1}$, the percentages of compounds exhibiting good recovery values between 70 and $120 \%$ were $82 \%$ in rye, $76 \%$ in wheat, $75 \%$ in barley, and $33 \%$ in rice. Among the cereals injected, and as mentioned before, rice is the most difficult matrix because of the relatively high amount of fat. At low concentrations, the pesticides may be discriminated by the high signal to noise of the co-extractive components of rice. Some non-polar compounds may also remain in the fat precipitate, such as tralomethrin (log P: 5). At $0.02 \mathrm{mg} \mathrm{kg}^{-1}$, good recoveries were obtained with rye, wheat, barley, and rice for $90 \%, 81 \%, 92 \%$, and $90 \%$ of the compounds, respectively. At $0.1 \mathrm{mg} \mathrm{kg}^{-1}, 94 \%$ of the compounds showed good recoveries in rye, $89 \%$ showed good recoveries in wheat, $94 \%$ showed good recoveries in barley, and $95 \%$ showed good recoveries in rice. Some compounds exhibited poor recoveries for all four matrices at all three concentrations studied, e.g., carvone, cycloxidim, chloridazon, cyromazine, and 8-hydroxyquinoline.

RSDs obtained for almost all the compounds were below $20 \%$ except for some compounds analysed in barley and rice at the lowest concentration of $0.01 \mathrm{mg} \mathrm{kg}^{-1}$. 
Intra-day precision and inter-day precision

The intra-day precision is influenced by many factors, such as the efficiency of the extraction procedure and potential errors during the extraction. It is also influenced by the instrument calibration and stability during the sequence; an internal mass calibration with perfluorotributylamine was performed before each injection on the TOFMS, to improve the resolution and accuracy of mass operation. Another parameter that may influence the results is the different types of cereals used for this study, which exhibited different responses depending on the matrix effect. The poor recoveries obtained for rice and barley at $0.01 \mathrm{mg} \mathrm{kg}^{-1}$ were the main reason why only $40 \%$ of the compounds showed an RSD for intra-day precision below $20 \%$. The results were quite different at 0.02 and $0.1 \mathrm{mg} \mathrm{kg}^{-1}$, at which almost all compounds showed an intra-day precision below $20 \%$

The inter-day precision indicates the reproducibility of the method applied on different days. In our study, the different matrices used were also considered. Only $33 \%$ of the compounds showed good inter-day precision at $0.01 \mathrm{mg} \mathrm{kg}^{-1}$, whereas $84 \%$ of the compounds showed good reproducibility below $20 \%$ at $0.02 \mathrm{mg} \mathrm{kg}^{-1}$, and $98 \%$ of the compounds showed good inter-day precision standard deviation at $0.1 \mathrm{mg} \mathrm{kg}^{-1}$.

\section{Uncertainty}

The results of uncertainty were consistent with the intra-day and inter-day precision results. Figure 4 shows the estimated uncertainty obtained at the three concentrations. Only $58 \%$ of the compounds showed low uncertainty below $50 \%$ at $0.01 \mathrm{mg} \mathrm{kg}^{-1}$. At $0.02 \mathrm{mg} \mathrm{kg}^{-1}$ and $0.1 \mathrm{mg} \mathrm{kg}^{-1}, 90 \%$ and $98 \%$ of the compounds showed low uncertainty, respectively. On the basis of the recovery and uncertainty results, the LOQs of the method ranged between 0.01 and $0.02 \mathrm{mg} \mathrm{kg}^{-1}$.

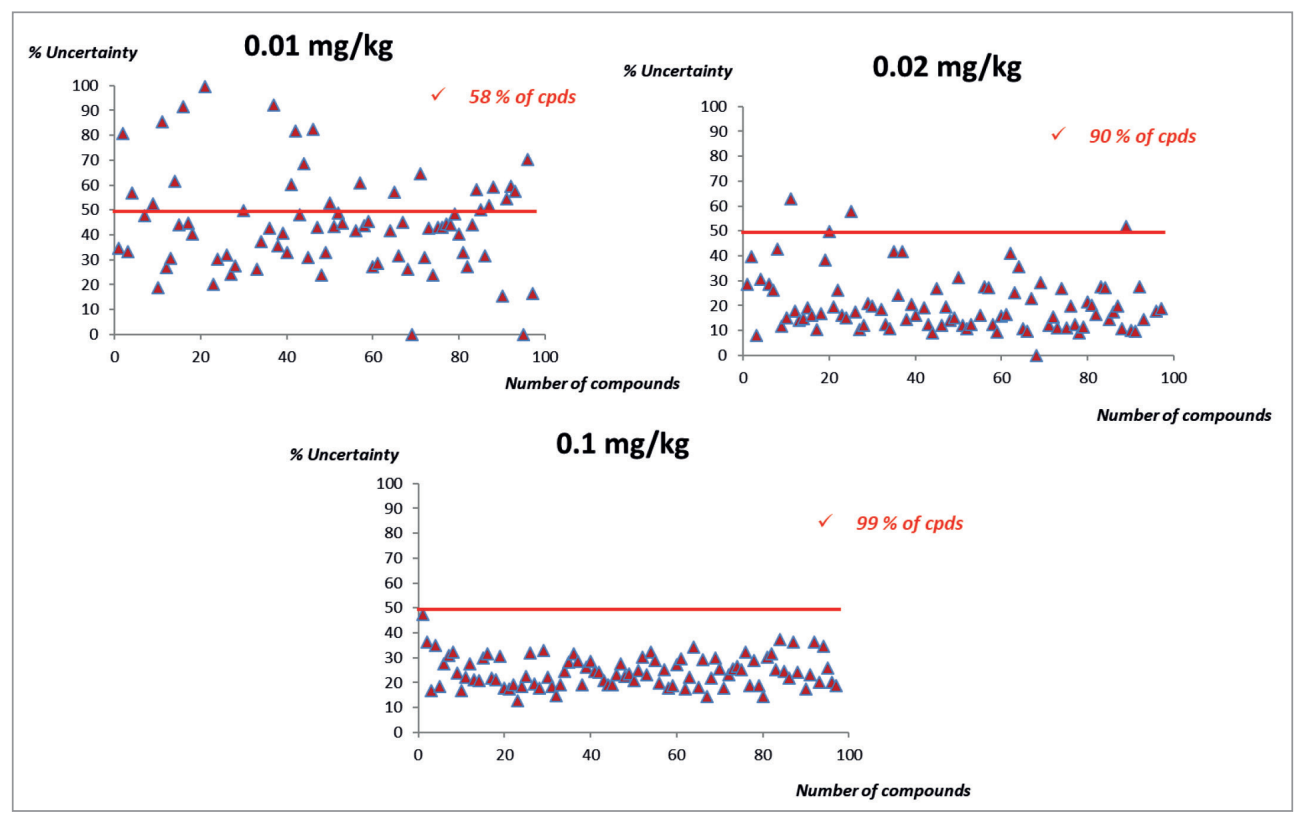

Figure 4. Uncertainty estimation in percentage obtained for the 102 compounds at $0.01,0.02$ and $0.1 \mathrm{mg} \mathrm{kg}^{-1}$.

\section{Matrix effect}

The matrix effect is a well-known problem in GC-EI [22] that can influence the accuracy of the results, producing signal suppression or enhancement depending on the compound. Matrix effects can be decreased through efficient sample preparation methods resulting in very clean extracts and therefore less interference. However, this approach may also lead to loss of analytes. Matrix effects are also decreased with dilution of the sample extract. Another way to diminish the matrix effect is to use HRMS; the accurate 
mass measurements yielded by HRMS decrease the chance of isobar detection, thus decreasing the matrix effect. According to our laboratory experience, rye was chosen as a representative matrix among the cereals included in the present study. Rye matrix provides good protection of the analytes and has a moderate matrix effect compared with those in other types of cereal matrices. Thus, matrix-matched calibration standards are commonly prepared with rye. The matrix effects presented in this study for barley, wheat, and rice were therefore calculated as percentage increases or decreases in response, normalized to that for rye. Figure 5 shows the matrix effects obtained with the comparison of slopes of the calibration curves prepared with each matrix. The results indicated that $94 \%$ of the compounds in wheat showed a weak matrix effect compared with rye $(\leq \pm 20 \%$ signal suppression or enhancement). Only $6 \%$ of the compounds showed a moderate matrix effect (|20-50|\% signal enhancement or suppression). In barley, $83 \%$ of the compounds showed a weak or non-significant matrix effect, $14 \%$ showed a moderate matrix effect, and $3 \%$ showed a strong matrix effect ( $\geq \pm 50 \%$ signal suppression or enhancement). In rice, $77 \%$ of the compounds showed a weak matrix effect, $21 \%$ of the compounds showed a moderate matrix effect, and only $2 \%$ of the compounds showed a strong matrix effect. Most of the compounds that showed any matrix effect at all exhibited a signal enhancement (approximately $60 \%$ of the compounds in wheat and rice, and $88 \%$ of the compounds in barley). The combination of an effective extraction method and a relatively high accurate mass measurement decreases the matrix effect. Therefore, the quantification of any cereal sample could be performed with a matrix-matched calibration prepared in rye.

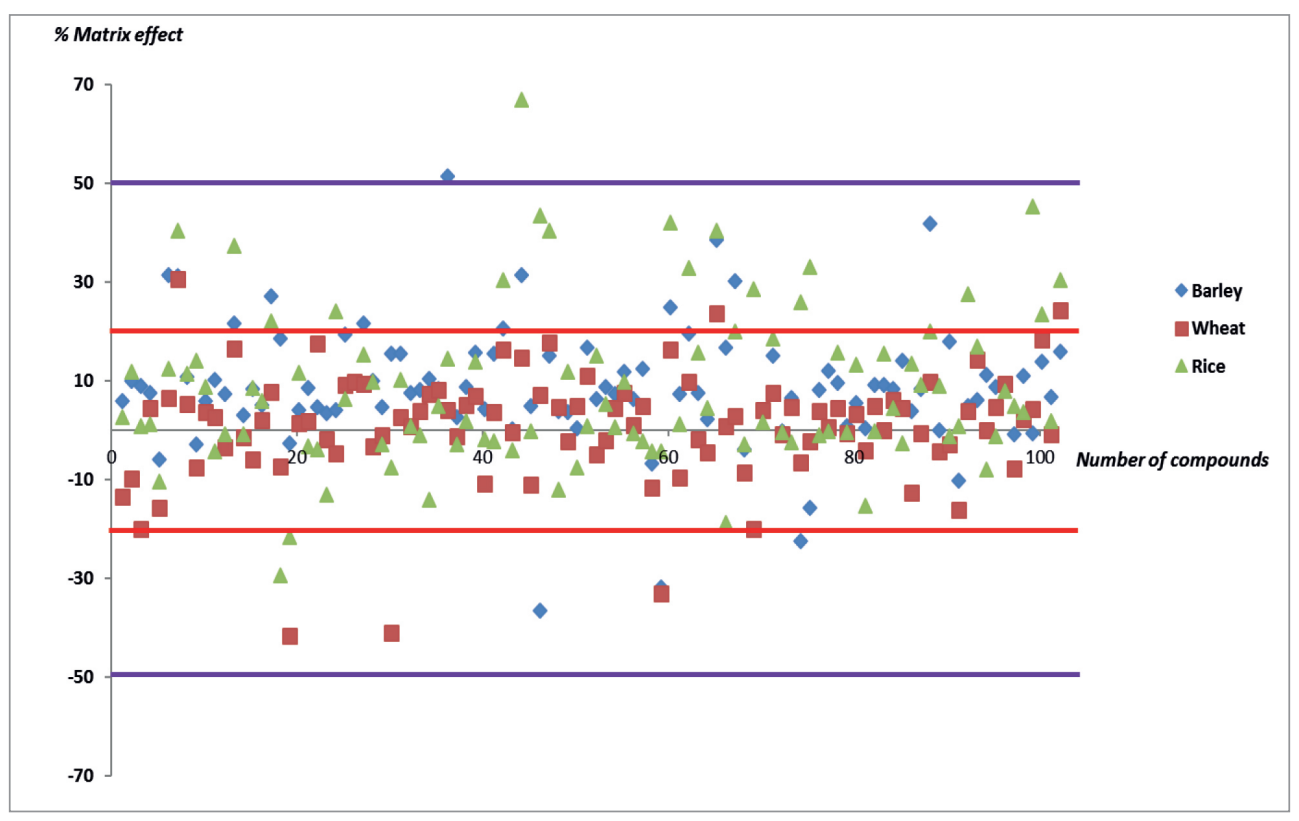

Figure 5. Percentage of matrix effect obtained from the comparison of slopes of matrix-matched calibrations of wheat, barley and rice to the slope of matrix-matched calibration prepared with rye.

\section{Real samples}

Only one pesticide was detected in real cereal samples, piperonyl butoxide, which is not included in the EU monitoring program for cereals [23]. Piperonyl butoxide is used as an insecticide synergist. It was detected in two parboiled rice samples, one jasmine rice sample, and one basmati rice sample at concentrations of $0.020,0.021,0.055$ and $0.113 \mathrm{mg} \mathrm{kg}^{-1}$, respectively. Piperonyl butoxide was detected at a high concentration exceeding the MRL of $0.060 \mathrm{mg} \mathrm{kg}^{-1}$, only in jasmine rice. The presented analytical method and evaluation approach was also applied to the green beans sample of the European Union Proficiency Test for screening methods (EUPT-SM10). All the spiked compounds were identified, among them, etoxazole, isopyrazam, metrafenone, penflufen, pentachloroaniline, penthiopyrad, and proquinazid, 
which demonstrate the applicability of the screening method described in this paper not only for cereal samples, but also for fruits and vegetables.

\section{CONCLUSION}

In recent years, the application of GC-TOFMS has been demonstrated to be a valuable and highly effective analytical tool in the analysis of pesticide residues in food. High mass accuracy TOF instruments can produce spectra with narrow mass peaks enabling high mass resolution. The benefit of high resolution is the elimination of background interference by using narrow mass window settings for extracting target ions, thus providing high selectivity. The resolution required for pesticide screening at lower concentrations depends on the complexity of the matrix analysed. High sensitivity is considered necessary for each application in food and pesticide food control. Cereals have relatively high lipid content, and the amount of interfering matrix retrieved in the extracts may affect the results. Accurate results are obtained through a combination of highly effective extraction procedures and instrumentation with adequate resolving power. The SDLs for cereals assessed without the use of any standards, through the citrate buffered QuEChERS method followed by GC-TOFMS analysis at $12000 \mathrm{FWHM}$, were in the range of 0.01 to $0.1 \mathrm{mg} \mathrm{kg}^{-1} \mathrm{or} \mathrm{higher}$ Considering the injection of standards for identification, $85 \%$ of the compounds would show an SDL of 0.01 $\mathrm{mg} \mathrm{kg}^{-1}$. Therefore, the recommendation for third countries laboratories disposing of mass spectrometry of insufficient resolution to use standards for the identification of compounds if they are economically unable to switch to instruments offering higher mass resolving power and higher mass accuracy. Simultaneous screening and quantification are possible with HRMS. On the basis of recovery studies and uncertainty estimation, almost all the compounds achieved an LOQ between 0.01 and $0.02 \mathrm{mg} \mathrm{kg}^{-1}$.

\section{Acknowledgments}

The current study was performed within the framework of the European Union Reference Laboratory (EURL) for pesticide residues in cereals and feeding stuff financed by the European Commission.

\section{REFERENCES}

1. Balogh, M. P. LCGC Europe, 2004, 17 (3), pp 152-159. Available from: https://pdfs.semanticscholar. org/6333/d74b2eac8f3752ab7b9690467913895ffb6a.pdf

2. Gómez-Ramos, M. M.; Ferrer, C.; Malato, O.; Agüera, A.; Fernández-Alba, A. R. J Chromatogr A., 2013, 1287, pp 24-37 (https://doi.org/10.1016/j.chroma.2013.02.065).

3. Alder, L.; Steinborn, A.; Bergelt, S. J. AOAC Int., 2011, 94 (6), pp 1661-1673 (https://doi.org/10.5740/ jaoacint.SGEAIder).

4. Portolés, T.; Mol, J. G. J.; Sancho, J. V.; Hernández, F. J. Chromatogr. A., 2014, 1339, pp 145-153 (https://doi.org/10.1016/j.chroma.2014.03.001).

5. Wang, X.; Li, P.; Zhang, W.; Zhang, Q.; Ma, F.; Yu, L.; Wang, L. J. Sep. Sci., 2012, 35 (13), pp 16341643 (https://doi.org/10.1002/jssc.201100863).

6. Zhang, F.; Wang, H.; Zhang, L.; Zhang, J.; Fan, R.; Yu, C.; Wang, W.; Guo, Y. Talanta, 2014, 128, pp 156-163 (https://doi.org/10.1016/j.talanta.2014.04.068).

7. Cheng, Z.; Dong, F.; Xu, J.; Wu, X.; Chen, Z.; Pan, X.; Gan, J.; Zhen, Y. Food Chem., 2017, 231, pp 365-373 (https://doi.org/10.1016/j.foodchem.2017.03.157).

8. Mol, H. G.; Tienstra, M.; Zomer, P. Anal. Chim. Acta., 2016, 935, pp 161-172 (https://doi.org/10.1016/j. aca.2016.06.017).

9. Goon, A.; Khan, Z.; Oulkar, D.; Shinde, R.; Gaikwad, S.; Banerjee, K. J. Chromatogr. A., 2018, 1532, pp 105-111 (https://doi.org/10.1016/j.chroma.2017.11.066).

10. Ates, E.; Godula, M.; Stroka, J.; Senyuva, H. Food Chem., 2014, 142, pp 276-284 (https://doi. org/10.1016/j.foodchem.2013.07.054).

11. Agüera, A.; Martínez-Piernas, A. B.; Campos-Mañas, M. C. Analytical Strategies Used in HRMS. In: Romero-González, R.; Frenich, A. G. (Eds) Applications in High Resolution Mass Spectrometry: Food 
Safety and Pesticide Residue Analysis, Elsevier, 2017, Chapter 3, pp 59-82.

12. http://www.foodcomp.dk/ [Accessed 3 November 2019].

13. Directive 2002/32/EC of the European Parliament and of the Council of 7 May 2002 on undesirable substances in animal feed - Council statement, Off. J. Eur. Comm., No. L140/10, May 30, 2002. Available from: https://eur-lex.europa.eu/eli/dir/2002/32/oj

14. European Commission-Directorate general for health and food safety - Guidance document on analytical quality control and validation procedures for pesticide residues analysis in food and feed. Eur. Comm. Heal. Consum. Prot. Dir. 2018, pp 2-44. Available from: https://ec.europa.eu/food/sites/ food/files/plant/docs/pesticides_mrl_guidelines_wrkdoc_2017-11813.pdf

15. Herrmann, S. S.; Poulsen, M. E. J. Chromatogr. A., 2015, 1423, pp 47-53 (https://doi.org/10.1016/j. chroma.2015.10.086).

16. European Standard EN15662 - Foods of plant origin - Determination of pesticide residues using GCMS and / or LC-MS/MS following acetonitrile extraction / partitioning and cleanup by dispersive SPEQuEChERS-method. UK, 2008.

17. Hakme, E.; Lozano, A.; Gomez-Ramos, M. M.; Hernando, M. D.; Fernandez-Alba, A. R. Chemosphere, 2017, 184, pp 1310-1319 (https://doi.org/10.1016/j.chemosphere.2017.06.089).

18. Berendsen, B. J. A.; Stolker, L. A. M.; Nielen, M. W. F. J. Am. Soc. Mass Spectrom., 2013, 24 (1), pp 154-163 (https://doi.org/10.1007/s13361-012-0501-0).

19. Ramanathan, R.; Jemal, M.; Ramagiri, S.; Xia, Y. Q.; Humpreys. W. G.; Olah, T.; Korfmacher, W. A. J. Mass Spectrom., 2011, 46 (6), pp 595-601 (https://doi.org/10.1002/jms.1921).

20. Eppe, G.; Focant, J. F.; Pirard, C.; De Pauw, E. Talanta, 2004, 63 (5), pp 1135-1146 (https://doi. org/10.1016/j.talanta.2004.05.056).

21. US Food \& Drug Administration. Office of Foods and Veterinary Medicine - Acceptance Criteria for Confirmation of Identity of Chemical Residues using Exact Mass Data within the Office of Foods and Veterinary Medicine, US, 2015.

22. Ucles, S.; Lozano, A.; Sosa, A.; Parrilla Vazquez, P.; Valverde, A.; Fernandez-Alba, A. R. Talanta, 2017, 174, pp 72-81 (https://doi.org/10.1016/j.talanta.2017.05.068).

23. Commission implementing regulation (EU) 2018/555 of 9 April 2018 concerning a coordinated multiannual control programme of the Union for 2019, 2020 and 2021 to ensure compliance with maximum residue levels of pesticides and to assess the consumer exposure, Off. J. Eur. Comm, 2018. Available from: http://data.europa.eu/eli/reg_impl/2018/555/oj 


\section{Supplementary Material}

The database of 102 compounds including: CAS number, retention times, molecular formula and exact mass of the compounds, and the formula, neutral mass and exact ion mass of fragment ions.

\begin{tabular}{|c|c|c|c|c|c|c|c|c|}
\hline \multicolumn{2}{|r|}{ Compounds } & $\begin{array}{c}\text { CAS } \\
\text { number }\end{array}$ & Rt (min) & $\begin{array}{c}\text { Exact molecular } \\
\text { mass }\end{array}$ & Molecular formula & Ion formula & $M^{+}, M+2$ & Neutral mass \\
\hline 1 & 1-Naphthylacetic acid & $86-87-3$ & 13.3 & 186.068080 & $\mathrm{C} 12 \mathrm{H} 10 \mathrm{O} 2$ & $\begin{array}{l}\text { C11H9 } \\
\mathrm{C} 9 \mathrm{H} 7 \\
\mathrm{C} 11 \mathrm{H} 7\end{array}$ & $\begin{array}{l}141.069876 \\
115.054226 \\
139.054226\end{array}$ & $\begin{array}{l}141.070425 \\
115.054775 \\
139.054775\end{array}$ \\
\hline 2 & 1-Naphtylacetamide & $86-86-2$ & 13.2 & 185.084064 & $\mathrm{C} 12 \mathrm{H} 11 \mathrm{NO}$ & $\begin{array}{c}\mathrm{C} 12 \mathrm{H} 11 \mathrm{NO} \\
\mathrm{C} 9 \mathrm{H} 7 \\
\mathrm{C} 11 \mathrm{H} 10\end{array}$ & $\begin{array}{l}185.083515 \\
115.054226 \\
142.077701\end{array}$ & $\begin{array}{l}185.084064 \\
115.054775 \\
142.078250\end{array}$ \\
\hline 3 & 8-Hydroxyquinoline & $148-24-3$ & 7.7 & 145.052764 & $\mathrm{C} 9 \mathrm{H} 7 \mathrm{NO}$ & $\begin{array}{c}\mathrm{C} 9 \mathrm{H} 7 \mathrm{NO} \\
\mathrm{C} 8 \mathrm{H} 7 \mathrm{~N} \\
\mathrm{C} 7 \mathrm{H} 6\end{array}$ & $\begin{array}{c}145.052215 \\
117.057300 \\
90.046401\end{array}$ & $\begin{array}{c}145.052764 \\
117.057849 \\
90.046950\end{array}$ \\
\hline 4 & Acetochlor & $34256-81-1$ & 12.4 & 269.118256 & $\mathrm{C} 14 \mathrm{H} 20 \mathrm{CINO} 2$ & $\begin{array}{l}\mathrm{C} 10 \mathrm{H} 12 \mathrm{~N} \\
\mathrm{C} 9 \mathrm{H} 10 \mathrm{~N} \\
\mathrm{C} 11 \mathrm{H} 12 \mathrm{NO}\end{array}$ & $\begin{array}{l}146.096425 \\
132.080775 \\
174.091340\end{array}$ & $\begin{array}{l}146.096974 \\
132.081324 \\
174.091889\end{array}$ \\
\hline 5 & Aclonifen & $74070-46-5$ & 18.2 & 264.030171 & $\mathrm{C} 12 \mathrm{H} 9 \mathrm{CIN} 2 \mathrm{O} 3$ & $\begin{array}{c}\mathrm{C} 12 \mathrm{H} 9 \mathrm{CIN} 2 \mathrm{O} 3 \\
\mathrm{C} 12 \mathrm{H} 8 \mathrm{~N} 2 \mathrm{O} 2 \\
\mathrm{C} 12 \mathrm{H} 9 \mathrm{NO}\end{array}$ & $\begin{array}{l}264.029622 \\
212.058029 \\
183.067865\end{array}$ & $\begin{array}{l}264.030171 \\
212.058578 \\
183.068414\end{array}$ \\
\hline 6 & Ametoctradin & $865318-97-4$ & 23.7 & 275.210995 & $\mathrm{C} 15 \mathrm{H} 25 \mathrm{~N} 5$ & $\begin{array}{l}\text { C8H10N5 } \\
\text { C9H12N5 } \\
\text { C8H11N5 }\end{array}$ & $\begin{array}{l}176.093071 \\
190.108721 \\
177.100896\end{array}$ & $\begin{array}{l}176.093620 \\
190.109270 \\
177.101445\end{array}$ \\
\hline 7 & Amidosulfuron & 120923-37-7 & 27.7 & 369.041294 & $\mathrm{C} 9 \mathrm{H} 15 \mathrm{~N} 5 \mathrm{O} 7 \mathrm{~S} 2$ & $\begin{array}{c}\text { C4H5N4O4S2 } \\
\text { C5H11N4S } \\
\text { C4H5N4O4(34S)S }\end{array}$ & $\begin{array}{l}236.974676 \\
159.069894 \\
238.971086\end{array}$ & $\begin{array}{l}236.975225 \\
159.070443 \\
238.971635\end{array}$ \\
\hline 8 & Amisulbrom & $348635-87-0$ & 23.8 & 464.957638 & $\mathrm{C} 13 \mathrm{H} 13 \mathrm{BrFN} 5 \mathrm{O} 4 \mathrm{~S} 2$ & $\begin{array}{c}\mathrm{C} 5 \mathrm{H} 2 \mathrm{~N} 5 \mathrm{O} 2 \mathrm{~S} 2 \\
\mathrm{C} 8 \mathrm{H} 4 \mathrm{FNO} 2 \mathrm{~S} 2 \\
\mathrm{C} 9 \mathrm{H} 6 \mathrm{BrFN}\end{array}$ & $\begin{array}{l}227.963656 \\
228.966202 \\
225.966214\end{array}$ & $\begin{array}{l}227.964205 \\
228.966751 \\
225.966763\end{array}$ \\
\hline 9 & Anthraquinone & $84-65-1$ & 13.9 & 208.052430 & $\mathrm{C} 14 \mathrm{H} 8 \mathrm{O} 2$ & $\begin{array}{c}\mathrm{C} 14 \mathrm{H} 8 \mathrm{O} 2 \\
\mathrm{C} 13 \mathrm{H} 8 \mathrm{O} \\
\mathrm{C} 12 \mathrm{H} 7\end{array}$ & $\begin{array}{l}208.051880 \\
180.056966 \\
151.054226\end{array}$ & $\begin{array}{l}208.052429 \\
180.057515 \\
151.054775\end{array}$ \\
\hline
\end{tabular}


The database of 102 compounds including: CAS number, retention times, molecular formula and exact mass of the compounds, and the formula, neutral mass and exact ion mass of fragment ions. (Cont.)

\begin{tabular}{|c|c|c|c|c|c|c|c|c|}
\hline & Compounds & $\begin{array}{c}\text { CAS } \\
\text { number }\end{array}$ & Rt (min) & $\begin{array}{c}\text { Exact molecular } \\
\text { mass }\end{array}$ & Molecular formula & Ion formula & $M^{+}, M+2$ & Neutral mass \\
\hline 10 & Benalaxyl & $71626-11-4$ & 19.1 & 325.167794 & $\mathrm{C} 2 \mathrm{OH} 23 \mathrm{NO} 3$ & $\begin{array}{l}\mathrm{C} 11 \mathrm{H} 14 \mathrm{NO} \\
\mathrm{C} 12 \mathrm{H} 16 \mathrm{NO} 2 \\
\mathrm{C} 13 \mathrm{H} 16 \mathrm{NO} 3\end{array}$ & $\begin{array}{l}176.106990 \\
206.117555 \\
234.112470\end{array}$ & $\begin{array}{l}176.107539 \\
206.118104 \\
234.113019\end{array}$ \\
\hline 11 & Benfluralin & $1861-40-1$ & 10.1 & 335.109291 & $\mathrm{C} 13 \mathrm{H} 16 \mathrm{~F} 3 \mathrm{~N} 3 \mathrm{O} 4$ & $\begin{array}{l}\mathrm{C} 10 \mathrm{H} 9 \mathrm{~F} 3 \mathrm{~N} 3 \mathrm{O} 4 \\
\mathrm{C} 8 \mathrm{H} 5 \mathrm{~F} 3 \mathrm{~N} 3 \mathrm{O} 4 \\
\mathrm{C} 7 \mathrm{H} 5 \mathrm{~F} 3 \mathrm{~N} 2 \mathrm{O} 2\end{array}$ & $\begin{array}{l}292.053967 \\
264.022667 \\
206.029763\end{array}$ & $\begin{array}{l}292.054516 \\
264.023216 \\
206.030312\end{array}$ \\
\hline 12 & Biphenyl & $92-52-4$ & 7.8 & 154.078250 & $\mathrm{C} 12 \mathrm{H} 10$ & $\begin{array}{l}\mathrm{C} 12 \mathrm{H} 10 \\
\mathrm{C} 12 \mathrm{H} 9 \\
\mathrm{C} 12 \mathrm{H} 8\end{array}$ & $\begin{array}{l}154.077701 \\
153.069876 \\
152.062051\end{array}$ & $\begin{array}{l}154.078250 \\
153.070425 \\
152.062600\end{array}$ \\
\hline 13 & Bixafen & $581809-46-3$ & 27.0 & 413.030951 & $\mathrm{C} 18 \mathrm{H} 12 \mathrm{Cl} 2 \mathrm{~F} 3 \mathrm{~N} 3 \mathrm{O}$ & $\begin{array}{c}\mathrm{C} 18 \mathrm{H} 12 \mathrm{Cl}(37 \mathrm{Cl}) \mathrm{F} 3 \mathrm{~N} 3 \mathrm{O} \\
\mathrm{C} 18 \mathrm{H} 12 \mathrm{Cl} 2 \mathrm{~F} 3 \mathrm{~N} 3 \mathrm{O} \\
\mathrm{C} 6 \mathrm{H} 5 \mathrm{~F} 2 \mathrm{~N} 2 \mathrm{O}\end{array}$ & $\begin{array}{l}415.027453 \\
413.030403 \\
159.036445\end{array}$ & $\begin{array}{l}415.028002 \\
413.030952 \\
159.036994\end{array}$ \\
\hline 14 & Butralin & $33629-47-9$ & 14.5 & 295.153207 & $\mathrm{C} 14 \mathrm{H} 21 \mathrm{~N} 3 \mathrm{O} 4$ & $\begin{array}{c}\mathrm{C} 12 \mathrm{H} 16 \mathrm{~N} 3 \mathrm{O} 4 \\
\mathrm{C} 11 \mathrm{H} 14 \mathrm{~N} 3 \mathrm{O} 2 \\
\mathrm{C} 9 \mathrm{H} 10 \mathrm{~N} 3 \mathrm{O} 4\end{array}$ & $\begin{array}{l}266.113533 \\
220.108053 \\
224.066583\end{array}$ & $\begin{array}{l}266.114082 \\
220.108602 \\
224.067132\end{array}$ \\
\hline 15 & Carbophenothion & $786-19-6$ & 19.0 & 341.973862 & $\mathrm{C} 11 \mathrm{H} 16 \mathrm{ClO} 2 \mathrm{PS} 3$ & $\begin{array}{l}\text { C7(35Cl)H6S } \\
\text { C7(37Cl)H6S } \\
\text { C3H6ClOS }\end{array}$ & $\begin{array}{l}156.987326 \\
143.979501 \\
124.982241\end{array}$ & $\begin{array}{l}156.987875 \\
158.984925 \\
124.982790\end{array}$ \\
\hline 16 & Carfentrazone-ethyl & $128639-02-1$ & 19.2 & 411.036432 & $\mathrm{C} 15 \mathrm{H} 14 \mathrm{Cl} 2 \mathrm{~F} 3 \mathrm{~N} 3 \mathrm{O} 3$ & $\begin{array}{l}\text { C13H9F3N3O3 } \\
\text { C15H13F3N3O3 } \\
\text { C11H8CIF3N3O }\end{array}$ & $\begin{array}{l}312.059052 \\
340.090352 \\
290.030250\end{array}$ & $\begin{array}{l}312.059601 \\
340.090901 \\
290.030799\end{array}$ \\
\hline 17 & Carvone & 99-49--0 & 8.9 & 150.104465 & $\mathrm{C} 10 \mathrm{H} 14 \mathrm{O}$ & $\begin{array}{l}\mathrm{C} 7 \mathrm{H} 7 \\
\mathrm{C} 7 \mathrm{H} 9 \\
\mathrm{C} 6 \mathrm{H} 7\end{array}$ & $\begin{array}{l}91.054226 \\
93.069876 \\
79.054226\end{array}$ & $\begin{array}{l}91.054775 \\
93.070425 \\
79.054775\end{array}$ \\
\hline 18 & Chlorantraniliprole & $500008-45-7$ & 21.5 & 480.970792 & $\mathrm{C} 18 \mathrm{H} 14 \mathrm{BrCl} 2 \mathrm{~N} 5 \mathrm{O} 2$ & $\begin{array}{l}\mathrm{C} 13 \mathrm{H} 8 \mathrm{Cl} 2 \mathrm{~N} 2 \mathrm{O} \\
\mathrm{C} 9 \mathrm{H} 14 \mathrm{BrClN} 2 \mathrm{O} \\
\mathrm{C} 13 \mathrm{H} 8 \mathrm{CIN} 2 \mathrm{O}\end{array}$ & $\begin{array}{l}278.000820 \\
279.997253 \\
243.031967\end{array}$ & $\begin{array}{l}278.001369 \\
279.997802 \\
243.032516\end{array}$ \\
\hline 19 & Chloridazon & $2698-60-8$ & 19.4 & 221.035590 & $\mathrm{C} 10 \mathrm{H} 8 \mathrm{CIN} 3 \mathrm{O}$ & $\begin{array}{c}\mathrm{C} 10 \mathrm{H} 8 \mathrm{CIN} 3 \mathrm{O} \\
\mathrm{C} 10 \mathrm{H} 8(37 \mathrm{Cl}) \mathrm{N} 3 \mathrm{O} \\
\mathrm{C} 6 \mathrm{H} 5\end{array}$ & $\begin{array}{c}221.035041 \\
223.032091 \\
77.038576\end{array}$ & $\begin{array}{c}221.035590 \\
223.032640 \\
77.039125\end{array}$ \\
\hline
\end{tabular}


Hakme, E.; Herrmann, S. S.; Poulsen, M. E.

The database of 102 compounds including: CAS number, retention times, molecular formula and exact mass of the compounds, and the formula, neutral mass and exact ion mass of fragment ions. (Cont.)

\begin{tabular}{|c|c|c|c|c|c|c|c|c|}
\hline \multicolumn{2}{|r|}{ Compounds } & $\begin{array}{l}\text { CAS } \\
\text { number }\end{array}$ & Rt (min) & $\begin{array}{c}\text { Exact molecular } \\
\text { mass }\end{array}$ & Molecular formula & Ion formula & $M^{+}, M+2$ & Neutral mass \\
\hline 20 & Chloropropylate & $5836-10-2$ & 17.9 & 338.047651 & $\mathrm{C} 17 \mathrm{H} 16 \mathrm{Cl} 2 \mathrm{O} 3$ & $\begin{array}{c}\mathrm{C} 7 \mathrm{H} 4 \mathrm{ClO} \\
\mathrm{C} 13 \mathrm{H} 9 \mathrm{Cl} 2 \mathrm{O} \\
\mathrm{C} 6 \mathrm{H} 4 \mathrm{Cl}\end{array}$ & $\begin{array}{l}138.994519 \\
251.002500 \\
110.999604\end{array}$ & $\begin{array}{l}138.995068 \\
251.003046 \\
111.000153\end{array}$ \\
\hline 21 & Chlorthal-dimethyl & $1861-32-1$ & 14.4 & 329.902022 & $\underline{\mathrm{C} 10 \mathrm{H} 6 \mathrm{Cl} 4 \mathrm{O} 4}$ & $\begin{array}{c}\mathrm{C} 9 \mathrm{H} 3 \mathrm{Cl} 4 \mathrm{O} 3 \\
\mathrm{C} 10 \mathrm{H} 6 \mathrm{Cl} 4 \mathrm{O} 4 \\
\mathrm{C} 7 \mathrm{Cl} 3 \mathrm{O} 2\end{array}$ & $\begin{array}{l}298.883083 \\
329.901473 \\
220.895840\end{array}$ & $\begin{array}{l}298.883632 \\
329.902022 \\
220.896389\end{array}$ \\
\hline 22 & Cinidon-ethyl & $142891-20-1$ & 31.2 & 393.053465 & $\mathrm{C} 19 \mathrm{H} 17 \mathrm{Cl} 2 \mathrm{NO} 4$ & $\begin{array}{c}\mathrm{C} 17 \mathrm{H} 13 \mathrm{CINO} 4 \\
\mathrm{C} 19 \mathrm{H} 17 \mathrm{CINO} 4 \\
\mathrm{C} 15 \mathrm{H} 9 \mathrm{CINO} 4\end{array}$ & $\begin{array}{l}330.052763 \\
358.084063 \\
302.021463\end{array}$ & $\begin{array}{l}330.053312 \\
358.084612 \\
302.022012\end{array}$ \\
\hline 23 & Clodinafop-propargyl & $105512-06-9$ & 19.5 & 349.051715 & $\mathrm{C} 17 \mathrm{H} 13 \mathrm{CIFNO} 4$ & $\begin{array}{l}\text { C11H6CIFNO2 } \\
\text { C13H10CIFNO2 } \\
\text { C17H13CIFNO4 }\end{array}$ & $\begin{array}{l}238.006560 \\
266.037860 \\
349.051170\end{array}$ & $\begin{array}{l}238.007110 \\
266.038410 \\
349.051715\end{array}$ \\
\hline 24 & Cycloxydim & $101205-02-1$ & 24.0 & 325.171165 & $\mathrm{C} 17 \mathrm{H} 27 \mathrm{NO} 3 \mathrm{~S}$ & $\begin{array}{c}\mathrm{C} 10 \mathrm{H} 12 \mathrm{NO} 2 \\
\mathrm{C} 6 \mathrm{H} 6 \mathrm{NO} \\
\mathrm{C} 5 \mathrm{H} 9 \mathrm{~S}\end{array}$ & $\begin{array}{l}178.086255 \\
108.044390 \\
101.041948\end{array}$ & $\begin{array}{l}178.086804 \\
108.044939 \\
101.042497\end{array}$ \\
\hline 25 & Cyflufenamid & $180409-60-3$ & 17.7 & 412.121018 & $\mathrm{C} 2 \mathrm{OH} 17 \mathrm{~F} 5 \mathrm{~N} 2 \mathrm{O} 2$ & $\begin{array}{c}\mathrm{C} 7 \mathrm{H} 6 \\
\mathrm{C} 8 \mathrm{H} 2 \mathrm{~F} 4 \mathrm{~N} \\
\mathrm{C} 7 \mathrm{H} 7\end{array}$ & $\begin{array}{l}90.046401 \\
188.011787 \\
91.054226\end{array}$ & $\begin{array}{c}90.046950 \\
188.012336 \\
91.054775\end{array}$ \\
\hline 26 & Cyromazine & $66215-27-8$ & 11.2 & 166.096694 & C6H10N6 & $\begin{array}{l}\text { C5H7N6 } \\
\text { C6H9N6 } \\
\text { C4H5N4 }\end{array}$ & $\begin{array}{l}151.072670 \\
165.088320 \\
109.050872\end{array}$ & $\begin{array}{l}151.073219 \\
165.088869 \\
109.051421\end{array}$ \\
\hline 27 & Dialifos & $10311-84-9$ & 23.7 & 393.002510 & C14H17CINO4PS2 & $\begin{array}{c}\mathrm{C} 10 \mathrm{H} 7 \mathrm{CINO} 2 \\
\mathrm{C} 7 \mathrm{H} 4 \mathrm{O} \\
\mathrm{C} 10 \mathrm{H} 7(37 \mathrm{Cl}) \mathrm{NO} 2\end{array}$ & $\begin{array}{l}208.015983 \\
104.025666 \\
210.013033\end{array}$ & $\begin{array}{l}208.016532 \\
104.026215 \\
210.013582\end{array}$ \\
\hline 28 & Dichlobenil & $1194-65-6$ & 7.6 & 170.964255 & $\mathrm{C} 7 \mathrm{H} 3 \mathrm{Cl} 2 \mathrm{~N}$ & $\begin{array}{c}\mathrm{C} 7 \mathrm{H} 3 \mathrm{Cl} 2 \mathrm{~N} \\
\mathrm{C} 7 \mathrm{H} 3(37 \mathrm{Cl}) \mathrm{ClN} \\
\mathrm{C} 7 \mathrm{H} 2 \mathrm{~N}\end{array}$ & $\begin{array}{l}170.963706 \\
172.960756 \\
100.018174\end{array}$ & $\begin{array}{l}170.964255 \\
172.961305 \\
100.018723\end{array}$ \\
\hline 29 & Dichlofenthion & $97-17-6$ & 12.4 & 313.970011 & $\mathrm{C} 10 \mathrm{H} 13 \mathrm{Cl} 2 \mathrm{O} 3 \mathrm{PS}$ & $\begin{array}{c}\text { C6H5ClO3PS } \\
\text { C10H13ClO3PS } \\
\text { C8H9ClO3PS }\end{array}$ & $\begin{array}{l}222.938009 \\
279.000609 \\
250.969309 \\
\end{array}$ & $\begin{array}{l}222.938558 \\
279.001158 \\
250.969858 \\
\end{array}$ \\
\hline
\end{tabular}


The database of 102 compounds including: CAS number, retention times, molecular formula and exact mass of the compounds, and the formula, neutral mass and exact ion mass of fragment ions. (Cont.)

\begin{tabular}{|c|c|c|c|c|c|c|c|c|}
\hline & Compounds & $\begin{array}{c}\text { CAS } \\
\text { number }\end{array}$ & Rt (min) & $\begin{array}{c}\text { Exact molecular } \\
\text { mass }\end{array}$ & Molecular formula & Ion formula & $M^{+}, M+2$ & Neutral mass \\
\hline 30 & Dicrotofos & $141-66-2$ & 10.0 & 237.076612 & C8H16NO5P & $\begin{array}{c}\mathrm{C} 2 \mathrm{H} 6 \mathrm{O} 3 \mathrm{P} \\
\mathrm{C} 3 \mathrm{H} 6 \mathrm{NO} \\
\mathrm{C} 6 \mathrm{H} 1005 \mathrm{P}\end{array}$ & $\begin{array}{c}109.004909 \\
72.044390 \\
193.026039\end{array}$ & $\begin{array}{c}109.005458 \\
72.044939 \\
193.026588\end{array}$ \\
\hline 31 & Diflufenican & $83164-33-4$ & 20.1 & 394.074068 & $\mathrm{C} 19 \mathrm{H} 11 \mathrm{~F} 5 \mathrm{~N} 2 \mathrm{O} 2$ & $\begin{array}{c}\text { C13H7F3NO2 } \\
\text { C19H11F5N2O2 } \\
\text { C13H6F2N2O }\end{array}$ & $\begin{array}{l}266.042339 \\
394.073519 \\
246.036110\end{array}$ & $\begin{array}{l}266.042888 \\
394.074068 \\
246.036659\end{array}$ \\
\hline 32 & Dimetachlor & $50563-36-5$ & 12.5 & 255.102607 & $\mathrm{C} 13 \mathrm{H} 18 \mathrm{CINO} 2$ & $\begin{array}{c}\mathrm{C} 9 \mathrm{H} 12 \mathrm{~N} \\
\mathrm{C} 10 \mathrm{H} 12 \mathrm{CINO} \\
\mathrm{C} 9 \mathrm{H} 10 \mathrm{NO}\end{array}$ & $\begin{array}{l}134.096425 \\
197.060193 \\
148.075690\end{array}$ & $\begin{array}{l}134.096974 \\
197.060742 \\
148.076239\end{array}$ \\
\hline 33 & Dimethenamid & $87674-68-8$ & 12.5 & 275.074679 & $\mathrm{C} 12 \mathrm{H} 18 \mathrm{CINO} 2 \mathrm{~S}$ & $\begin{array}{c}\text { C8H12NS } \\
\text { C10H13CINOS } \\
\text { C8H10CINOS }\end{array}$ & $\begin{array}{l}154.068497 \\
230.040090 \\
203.016615\end{array}$ & $\begin{array}{l}154.069046 \\
230.040639 \\
203.017164\end{array}$ \\
\hline 34 & Dimoxystrobin & $149961-52-4$ & 21.1 & 326.163043 & $\mathrm{C} 19 \mathrm{H} 22 \mathrm{~N} 2 \mathrm{O} 3$ & $\begin{array}{c}\mathrm{C} 8 \mathrm{H} 6 \mathrm{~N} \\
\mathrm{C} 7 \mathrm{H} 5 \\
\mathrm{C} 11 \mathrm{H} 13 \mathrm{~N} 2 \mathrm{O} 2\end{array}$ & $\begin{array}{c}116.049475 \\
89.038576 \\
205.097154\end{array}$ & $\begin{array}{c}116.050024 \\
89.039125 \\
205.097703\end{array}$ \\
\hline 35 & Diniconazole & $83657-24-3$ & 18.1 & 325.074868 & $\mathrm{C} 15 \mathrm{H} 17 \mathrm{Cl} 2 \mathrm{~N} 3 \mathrm{O}$ & $\begin{array}{c}\mathrm{C} 11 \mathrm{H} 8 \mathrm{Cl} 2 \mathrm{~N} 3 \mathrm{O} \\
\mathrm{C} 11 \mathrm{H} 7 \mathrm{CIN} 3 \mathrm{O} \\
\mathrm{C} 8 \mathrm{H} 5 \mathrm{Cl}\end{array}$ & $\begin{array}{l}268.003894 \\
232.027216 \\
136.007429\end{array}$ & $\begin{array}{l}268.004443 \\
232.027765 \\
136.007978\end{array}$ \\
\hline 36 & Dioxathion & $78-34-2$ & 25.1 & 456.008753 & $\mathrm{C} 12 \mathrm{H} 26 \mathrm{O} 6 \mathrm{P} 2 \mathrm{~S} 4$ & $\begin{array}{c}\text { C8H16O4PS2 } \\
\text { C4H10O2PS2 } \\
\text { C4H10O2PS }\end{array}$ & $\begin{array}{l}271.022218 \\
184.985438 \\
153.013366\end{array}$ & $\begin{array}{l}271.022767 \\
184.985987 \\
153.013915\end{array}$ \\
\hline 37 & Ethalfluralin & $55283-68-6$ & 9.9 & 333.093641 & $\mathrm{C} 13 \mathrm{H} 14 \mathrm{~F} 3 \mathrm{~N} 3 \mathrm{O} 4$ & $\begin{array}{l}\text { C10H9F3N3O3 } \\
\text { C13H13F3N3O3 } \\
\text { C10H9F3N3O4 }\end{array}$ & $\begin{array}{l}276.059052 \\
316.090352 \\
292.053967\end{array}$ & $\begin{array}{l}276.059601 \\
316.090901 \\
292.054516\end{array}$ \\
\hline 38 & Ethofumesate & $26225-79-6$ & 13.5 & 286.087497 & $\mathrm{C} 13 \mathrm{H} 18 \mathrm{O} 5 \mathrm{~S}$ & $\begin{array}{c}\mathrm{C} 10 \mathrm{H} 9 \mathrm{O} 2 \\
\mathrm{C} 12 \mathrm{H} 15 \mathrm{O} 3 \\
\mathrm{C} 8 \mathrm{H} 9 \mathrm{O} 2\end{array}$ & $\begin{array}{l}161.059705 \\
207.101571 \\
137.059705\end{array}$ & $\begin{array}{l}161.060254 \\
207.102120 \\
137.060254\end{array}$ \\
\hline 39 & Etoxazole & $153233-91-1$ & 21.5 & 359.169685 & $\mathrm{C} 21 \mathrm{H} 23 \mathrm{~F} 2 \mathrm{NO} 2$ & $\begin{array}{c}\mathrm{C} 7 \mathrm{H} 3 \mathrm{~F} 2 \mathrm{O} \\
\mathrm{C} 18 \mathrm{H} 16 \mathrm{~F} 2 \mathrm{NO} \\
\mathrm{C} 13 \mathrm{H} 18 \mathrm{NO}\end{array}$ & $\begin{array}{l}141.014647 \\
300.119446 \\
204.138290\end{array}$ & $\begin{array}{l}141.015196 \\
300.119995 \\
204.138839\end{array}$ \\
\hline
\end{tabular}


The database of 102 compounds including: CAS number, retention times, molecular formula and exact mass of the compounds, and the formula, neutral mass and exact ion mass of fragment ions. (Cont.)

\begin{tabular}{|c|c|c|c|c|c|c|c|c|}
\hline & Compounds & $\begin{array}{c}\text { CAS } \\
\text { number }\end{array}$ & Rt (min) & $\begin{array}{c}\text { Exact molecular } \\
\text { mass }\end{array}$ & Molecular formula & Ion formula & $M^{+}, M+2$ & Neutral mass \\
\hline 40 & Etridiazole & $2593-15-9$ & 8.3 & 245.918819 & C5H5Cl3N2OS & $\begin{array}{c}\text { C3HCl2N2OS } \\
\text { C5H5Cl2N2OS } \\
\text { C5H5(35Cl)CIN2OS }\end{array}$ & $\begin{array}{l}182.918117 \\
210.949417 \\
212.946467\end{array}$ & $\begin{array}{l}182.918666 \\
210.949966 \\
212.947016\end{array}$ \\
\hline 41 & Etrimfos & $38260-54-7$ & 11.8 & 292.064668 & $\mathrm{C} 10 \mathrm{H} 17 \mathrm{~N} 2 \mathrm{O} 4 \mathrm{PS}$ & $\begin{array}{c}\mathrm{C} 9 \mathrm{H} 13 \mathrm{~N} 2 \mathrm{O} 2 \\
\mathrm{C} 10 \mathrm{H} 17 \mathrm{~N} 2 \mathrm{O} 4 \mathrm{PS} \\
\mathrm{C} 7 \mathrm{H} 9 \mathrm{~N} 2 \mathrm{O} 2\end{array}$ & $\begin{array}{l}181.097154 \\
292.064119 \\
153.065853\end{array}$ & $\begin{array}{l}181.097703 \\
292.064668 \\
153.066402\end{array}$ \\
\hline 42 & Famoxadone & $131807-57-3$ & 29.8 & 374.126658 & $\mathrm{C} 22 \mathrm{H} 18 \mathrm{~N} 2 \mathrm{O} 4$ & $\begin{array}{c}\mathrm{C} 21 \mathrm{H} 18 \mathrm{~N} 2 \mathrm{O} 2 \\
\mathrm{C} 15 \mathrm{H} 12 \mathrm{O} 2 \\
\mathrm{C} 14 \mathrm{H} 12 \mathrm{O}\end{array}$ & $\begin{array}{l}330.136279 \\
224.083181 \\
196.088266\end{array}$ & $\begin{array}{l}330.136828 \\
224.083730 \\
196.088815\end{array}$ \\
\hline 43 & Fenchlorphos & $299-84-3$ & 13.1 & 319.899739 & С8H8Cl3O3PS & $\begin{array}{c}\mathrm{C} 8 \mathrm{H} 8 \mathrm{Cl} 2 \mathrm{O} 3 \mathrm{PS} \\
\mathrm{C} 8 \mathrm{H} 8(37 \mathrm{Cl}) \mathrm{ClO} 3 \mathrm{PS} \\
\mathrm{C} 2 \mathrm{H} 6 \mathrm{O} 2 \mathrm{PS}\end{array}$ & $\begin{array}{l}284.930337 \\
286.927387 \\
124.982066\end{array}$ & $\begin{array}{l}284.930886 \\
286.927936 \\
124.982615\end{array}$ \\
\hline 44 & Fenoxaprop-p-ethyl & $71283-80-2$ & 23.9 & 361.071702 & C18H16CINO5 & $\begin{array}{l}\text { C15H11CINO3 } \\
\text { C18H16CINO5 } \\
\text { C13H8CINO3 }\end{array}$ & $\begin{array}{l}288.042198 \\
361.071152 \\
261.018723\end{array}$ & $\begin{array}{l}288.042747 \\
361.071701 \\
261.019272\end{array}$ \\
\hline 45 & Flonicamid & $158062-67-0$ & 9.4 & 229.046295 & $\mathrm{C} 9 \mathrm{H} 6 \mathrm{~F} 3 \mathrm{~N} 3 \mathrm{O}$ & $\begin{array}{l}\text { C7H3F3NO } \\
\text { C6H3F3N } \\
\text { C6H4F3N }\end{array}$ & $\begin{array}{l}174.016124 \\
146.021209 \\
147.029034\end{array}$ & $\begin{array}{l}174.016673 \\
146.021758 \\
147.029583\end{array}$ \\
\hline 46 & Fluazinam & $79622-59-6$ & 15.1 & 463.951380 & $\mathrm{C} 13 \mathrm{H} 4 \mathrm{Cl} 2 \mathrm{~F} 6 \mathrm{~N} 4 \mathrm{O} 4$ & $\begin{array}{c}\mathrm{C} 13 \mathrm{H} 4 \mathrm{Cl} 2 \mathrm{~F} 6 \mathrm{~N} 3 \mathrm{O} 2 \\
\mathrm{C} 13 \mathrm{H} 4 \mathrm{Cl} 2 \mathrm{~F} 6 \mathrm{~N} 2 \\
\mathrm{C} 13 \mathrm{H} 4(37 \mathrm{Cl}) \mathrm{ClF} 6 \mathrm{~N} 3 \mathrm{O} 2\end{array}$ & $\begin{array}{l}417.957927 \\
371.965023 \\
419.954977\end{array}$ & $\begin{array}{l}417.958476 \\
371.965572 \\
419.955526\end{array}$ \\
\hline 47 & Flucythrinate I and II & $70124-77-5$ & $\begin{array}{l}26.6 \\
27.0\end{array}$ & 451.159515 & $\mathrm{C} 26 \mathrm{H} 23 \mathrm{~F} 2 \mathrm{NO} 4$ & $\begin{array}{c}\text { C8H7F2O } \\
\text { C11H13F2O } \\
\text { C14H11NO2 }\end{array}$ & $\begin{array}{l}157.045947 \\
199.092897 \\
225.078430\end{array}$ & $\begin{array}{l}157.046496 \\
199.093446 \\
225.078979\end{array}$ \\
\hline 48 & Flufenacet & $142459-58-3$ & 14.1 & 363.066461 & $\mathrm{C} 14 \mathrm{H} 13 \mathrm{~F} 4 \mathrm{~N} 3 \mathrm{O} 2 \mathrm{~S}$ & $\begin{array}{c}\mathrm{C} 9 \mathrm{H} 10 \mathrm{FN} \\
\mathrm{C} 5 \mathrm{H} 2 \mathrm{~F} 3 \mathrm{~N} 2 \mathrm{O} 2 \mathrm{~S} \\
\mathrm{C} 8 \mathrm{H} 7 \mathrm{FN}\end{array}$ & $\begin{array}{l}151.079178 \\
210.978360 \\
136.055703\end{array}$ & $\begin{array}{l}151.079727 \\
210.978909 \\
136.056252\end{array}$ \\
\hline 49 & Flumetralin & $62924-70-3$ & 16.2 & 421.045247 & $\mathrm{C} 16 \mathrm{H} 12 \mathrm{CIF} 4 \mathrm{~N} 3 \mathrm{O} 4$ & $\begin{array}{c}\mathrm{C} 7 \mathrm{H} 5 \mathrm{ClF} \\
\mathrm{C} 7 \mathrm{H} 5(37 \mathrm{Cl}) \mathrm{F} \\
\mathrm{C} 16 \mathrm{H} 11 \mathrm{ClF} 4 \mathrm{~N} 3 \mathrm{O} 3\end{array}$ & $\begin{array}{l}143.005832 \\
145.002882 \\
404.041958\end{array}$ & $\begin{array}{l}143.006381 \\
145.003431 \\
404.042507\end{array}$ \\
\hline
\end{tabular}


The database of 102 compounds including: CAS number, retention times, molecular formula and exact mass of the compounds, and the formula, neutral mass and exact ion mass of fragment ions. (Cont.)

\begin{tabular}{|c|c|c|c|c|c|c|c|c|}
\hline & Compounds & $\begin{array}{c}\text { CAS } \\
\text { number }\end{array}$ & Rt (min) & $\begin{array}{c}\text { Exact molecular } \\
\text { mass }\end{array}$ & Molecular formula & Ion formula & $M^{+}, M+2$ & Neutral mass \\
\hline 50 & Flumioxazin & 103361-09-7 & 27.9 & 354.101586 & $\mathrm{C} 19 \mathrm{H} 15 \mathrm{FN} 2 \mathrm{O} 4$ & $\begin{array}{l}\mathrm{C} 19 \mathrm{H} 15 \mathrm{FN} 2 \mathrm{O} 4 \\
\mathrm{C} 13 \mathrm{H} 8 \mathrm{FN} 2 \mathrm{O} 3 \\
\mathrm{C} 18 \mathrm{H} 15 \mathrm{FN} 2 \mathrm{O} 3\end{array}$ & $\begin{array}{l}354.101037 \\
259.051347 \\
326.106122\end{array}$ & $\begin{array}{l}354.101586 \\
259.051896 \\
326.106671\end{array}$ \\
\hline 51 & Fluopicolide & $239110-15-7$ & 19.7 & 381.965431 & $\mathrm{C} 14 \mathrm{H} 8 \mathrm{Cl} 3 \mathrm{~F} 3 \mathrm{~N} 2 \mathrm{O}$ & $\begin{array}{c}\mathrm{C} 7 \mathrm{H} 3 \mathrm{Cl} 2 \mathrm{O} \\
\mathrm{C} 14 \mathrm{H} 8 \mathrm{Cl} 2 \mathrm{~F} 3 \mathrm{~N} 2 \mathrm{O} \\
\mathrm{C} 6 \mathrm{H} 3 \mathrm{Cl} 2\end{array}$ & $\begin{array}{l}172.955547 \\
346.996029 \\
144.960632\end{array}$ & $\begin{array}{l}172.956096 \\
346.996578 \\
144.961181\end{array}$ \\
\hline 52 & Fluopyram & $658066-35-4$ & 15.3 & 396.046409 & C16H11CIF6N2O & $\begin{array}{c}\text { C8H4F3O } \\
\text { C7H4F3 } \\
\text { C8H7ClF3N2 }\end{array}$ & $\begin{array}{l}173.020875 \\
145.025960 \\
223.024436\end{array}$ & $\begin{array}{l}173.021424 \\
145.026509 \\
223.024985\end{array}$ \\
\hline 53 & Flurochloridone & $61213-25-0$ & 14.3 & 311.009153 & $\mathrm{C} 12 \mathrm{H} 10 \mathrm{Cl} 2 \mathrm{~F} 3 \mathrm{NO}$ & $\begin{array}{c}\text { C8H4F3NO } \\
\text { C8H7F3N } \\
\text { C12H10Cl2F3NO }\end{array}$ & $\begin{array}{l}187.023949 \\
174.052509 \\
311.008605\end{array}$ & $\begin{array}{l}187.024498 \\
174.053058 \\
311.009154\end{array}$ \\
\hline 54 & Flurprimidol & $56425-91-3$ & 12.5 & 312.108562 & $\mathrm{C} 15 \mathrm{H} 15 \mathrm{~F} 3 \mathrm{~N} 2 \mathrm{O} 2$ & $\begin{array}{c}\mathrm{C} 12 \mathrm{H} 8 \mathrm{~F} 3 \mathrm{~N} 2 \mathrm{O} 2 \\
\mathrm{C} 5 \mathrm{H} 3 \mathrm{~N} 2 \mathrm{O} \\
\mathrm{C} 8 \mathrm{H} 4 \mathrm{~F} 3 \mathrm{O} 2\end{array}$ & $\begin{array}{l}269.053238 \\
107.023989 \\
189.015790\end{array}$ & $\begin{array}{l}269.053787 \\
107.024538 \\
189.016339\end{array}$ \\
\hline 55 & Flurtamone & $96525-23-4$ & 22.2 & 333.097663 & $\mathrm{C} 18 \mathrm{H} 14 \mathrm{~F} 3 \mathrm{NO} 2$ & $\begin{array}{c}\mathrm{C} 8 \mathrm{H} 10 \mathrm{~N} \\
\mathrm{C} 18 \mathrm{H} 14 \mathrm{~F} 3 \mathrm{NO} 2 \\
\mathrm{C} 10 \mathrm{H} 8 \mathrm{~F} 3 \mathrm{~N}\end{array}$ & $\begin{array}{l}120.080775 \\
333.097114 \\
199.060334\end{array}$ & $\begin{array}{l}120.081324 \\
333.097663 \\
199.060883\end{array}$ \\
\hline 56 & Flutolanil & $66332-96-5$ & 16.6 & 323.113313 & $\mathrm{C} 17 \mathrm{H} 16 \mathrm{~F} 3 \mathrm{NO} 2$ & $\begin{array}{c}\mathrm{C} 8 \mathrm{H} 4 \mathrm{~F} 3 \mathrm{O} \\
\mathrm{C} 7 \mathrm{H} 4 \mathrm{~F} 3 \\
\mathrm{C} 17 \mathrm{H} 16 \mathrm{~F} 3 \mathrm{NO} 2\end{array}$ & $\begin{array}{l}173.020875 \\
145.025960 \\
323.112764\end{array}$ & $\begin{array}{l}173.021424 \\
145.026509 \\
323.113313\end{array}$ \\
\hline 57 & Fluxapyroxad & $907204-31-3$ & 21.3 & 381.090052 & $\mathrm{C} 18 \mathrm{H} 12 \mathrm{~F} 5 \mathrm{~N} 3 \mathrm{O}$ & $\begin{array}{c}\text { C6H5F2N2O } \\
\text { C18H12F5N3O } \\
\text { C12H6F3N }\end{array}$ & $\begin{array}{l}159.036445 \\
381.089503 \\
221.044684\end{array}$ & $\begin{array}{l}159.036994 \\
381.090052 \\
221.045233\end{array}$ \\
\hline 58 & Fonofos & $944-22-9$ & 11.3 & 246.030197 & $\mathrm{C} 10 \mathrm{H} 15 \mathrm{OPS} 2$ & $\begin{array}{c}\text { C2H6OPS } \\
\text { C4H10OPS } \\
\text { C10H15OPS2 }\end{array}$ & $\begin{array}{l}108.987151 \\
137.018451 \\
246.029648\end{array}$ & $\begin{array}{l}108.987700 \\
137.019000 \\
246.030197\end{array}$ \\
\hline 59 & Fuberidazole & $3878-19-1$ & 12.7 & 184.063663 & $\mathrm{C} 11 \mathrm{H} 8 \mathrm{~N} 2 \mathrm{O}$ & $\begin{array}{l}\mathrm{C} 11 \mathrm{H} 8 \mathrm{~N} 2 \mathrm{O} \\
\mathrm{C} 10 \mathrm{H} 8 \mathrm{~N} 2 \\
\mathrm{C} 10 \mathrm{H} 7 \mathrm{~N} 2\end{array}$ & $\begin{array}{l}184.063114 \\
156.068199 \\
155.060374\end{array}$ & $\begin{array}{l}184.063663 \\
156.068748 \\
155.060923\end{array}$ \\
\hline
\end{tabular}


Hakme, E.; Herrmann, S. S.; Poulsen, M. E.

The database of 102 compounds including: CAS number, retention times, molecular formula and exact mass of the compounds, and the formula, neutral mass and exact ion mass of fragment ions. (Cont.)

\begin{tabular}{|c|c|c|c|c|c|c|c|c|}
\hline & Compounds & $\begin{array}{c}\text { CAS } \\
\text { number }\end{array}$ & Rt (min) & $\begin{array}{c}\text { Exact molecular } \\
\text { mass }\end{array}$ & Molecular formula & Ion formula & $M^{+}, M+2$ & Neutral mass \\
\hline 60 & Furathiocarb & $65907-30-4$ & 22.2 & 382.156245 & $\mathrm{C} 18 \mathrm{H} 26 \mathrm{~N} 2 \mathrm{O} 5 \mathrm{~S}$ & $\begin{array}{c}\mathrm{C} 10 \mathrm{H} 11 \mathrm{O} 2 \\
\mathrm{C} 10 \mathrm{H} 10 \mathrm{O} 2 \mathrm{~S} \\
\mathrm{C} 7 \mathrm{H} 7 \mathrm{O}\end{array}$ & $\begin{array}{l}163.075356 \\
194.039603 \\
107.049140\end{array}$ & $\begin{array}{l}163.075905 \\
194.040152 \\
107.049690\end{array}$ \\
\hline 61 & Heptachlor & $76-44-8$ & 12.9 & 369.821096 & $\mathrm{C} 10 \mathrm{H} 5 \mathrm{Cl} 7$ & $\begin{array}{c}\mathrm{C} 5 \mathrm{H} 2 \mathrm{Cl} 6 \\
\mathrm{C} 5 \mathrm{H} 5 \mathrm{Cl} \\
\mathrm{C} 5 \mathrm{H} 2(37 \mathrm{Cl}) \mathrm{Cl} 5\end{array}$ & $\begin{array}{l}271.809619 \\
100.007429 \\
273.806669\end{array}$ & $\begin{array}{l}271.810168 \\
100.007978 \\
273.807218\end{array}$ \\
\hline 62 & Isocarbofos & $24353-61-5$ & 14.2 & 289.053769 & C11H16NO4PS & $\begin{array}{c}\mathrm{C} 7 \mathrm{H} 4 \mathrm{OS} \\
\mathrm{C} 7 \mathrm{H} 4 \mathrm{O} 2 \\
\mathrm{C} 6 \mathrm{H} 4 \mathrm{O}\end{array}$ & $\begin{array}{c}135.997738 \\
120.020581 \\
92.025666\end{array}$ & $\begin{array}{c}135.998287 \\
120.021130 \\
92.026215\end{array}$ \\
\hline 63 & Isofenfos & $25311-71-1$ & 15.2 & 345.116369 & $\mathrm{C} 15 \mathrm{H} 24 \mathrm{NO} 4 \mathrm{PS}$ & $\begin{array}{c}\mathrm{C} 7 \mathrm{H} 5 \mathrm{O} 2 \\
\mathrm{C} 9 \mathrm{H} 10 \mathrm{O} 4 \mathrm{P} \\
\mathrm{C} 7 \mathrm{H} 6 \mathrm{O} 4 \mathrm{P}\end{array}$ & $\begin{array}{l}121.028406 \\
213.031124 \\
184.999824\end{array}$ & $\begin{array}{l}121.028955 \\
213.031673 \\
185.000373\end{array}$ \\
\hline 64 & Isoprocarb & $2631-40-5$ & 8.9 & 193.110279 & $\mathrm{C} 11 \mathrm{H} 15 \mathrm{NO} 2$ & $\begin{array}{c}\mathrm{C} 8 \mathrm{H} 9 \mathrm{O} \\
\mathrm{C} 9 \mathrm{H} 12 \mathrm{O} \\
\mathrm{C} 8 \mathrm{H} 7\end{array}$ & $\begin{array}{l}121.064790 \\
136.088266 \\
103.054226\end{array}$ & $\begin{array}{l}121.065339 \\
136.088815 \\
103.054775\end{array}$ \\
\hline 65 & Isopyrazam & $881685-58-1$ & 23.9 & 359.180918 & $\mathrm{C} 2 \mathrm{OH} 23 \mathrm{~F} 2 \mathrm{~N} 3 \mathrm{O}$ & $\begin{array}{c}\text { C6H5F2N2O } \\
\text { C2OH23F2N3O } \\
\text { C12H10NO }\end{array}$ & $\begin{array}{l}159.036445 \\
359.180369 \\
184.075690\end{array}$ & $\begin{array}{l}159.036994 \\
359.180918 \\
184.076239\end{array}$ \\
\hline 66 & Isoxaflutole & $141112-90-0$ & 14.4 & 359.043914 & $\mathrm{C} 15 \mathrm{H} 12 \mathrm{~F} 3 \mathrm{NO} 4 \mathrm{~S}$ & $\begin{array}{c}\mathrm{C} 14 \mathrm{H} 8 \mathrm{~F} 3 \mathrm{NO} 2 \\
\mathrm{C} 7 \mathrm{H} 3 \mathrm{~F} 3 \mathrm{O} \\
\mathrm{C} 13 \mathrm{H} 7 \mathrm{~F} 3 \mathrm{O} 2\end{array}$ & $\begin{array}{l}279.050550 \\
160.013500 \\
252.039990\end{array}$ & $\begin{array}{l}279.050713 \\
160.013599 \\
252.039814\end{array}$ \\
\hline 67 & Isoxathion & $18854-01-8$ & 17.5 & 313.053769 & C13H16NO4PS & $\begin{array}{c}\text { CH57O } \\
\text { C9H7NOS } \\
\text { C11H12NO4PS }\end{array}$ & $\begin{array}{l}105.033491 \\
177.024287 \\
285.021920\end{array}$ & $\begin{array}{l}105.034040 \\
177.024836 \\
285.022469\end{array}$ \\
\hline 68 & Metazachlor & $67129-08-2$ & 14.9 & 277.098190 & $\mathrm{C} 14 \mathrm{H} 16 \mathrm{CIN} 3 \mathrm{O}$ & $\begin{array}{c}\mathrm{C} 9 \mathrm{H} 10 \mathrm{~N} \\
\mathrm{C} 11 \mathrm{H} 12 \mathrm{CINO} \\
\mathrm{C} 4 \mathrm{H} 5 \mathrm{~N} 2\end{array}$ & $\begin{array}{c}132.080775 \\
209.060193 \\
81.044724\end{array}$ & $\begin{array}{c}132.081324 \\
209.060742 \\
81.045273\end{array}$ \\
\hline 69 & Metobromuron & $3060-89-7$ & 7.0 & 258.000389 & $\mathrm{C} 9 \mathrm{H} 11 \mathrm{BrN} 2 \mathrm{O} 2$ & $\begin{array}{c}\mathrm{C} 7 \mathrm{H} 4 \mathrm{BrNO} \\
\mathrm{C} 6 \mathrm{H} 4 \mathrm{BrN} \\
\mathrm{C} 6 \mathrm{H} 4 \mathrm{~N}\end{array}$ & $\begin{array}{c}196.947076 \\
168.952161 \\
90.033825\end{array}$ & $\begin{array}{c}196.947625 \\
168.952710 \\
90.034374\end{array}$ \\
\hline
\end{tabular}


The database of 102 compounds including: CAS number, retention times, molecular formula and exact mass of the compounds, and the formula, neutral mass and exact ion mass of fragment ions. (Cont.)

\begin{tabular}{|c|c|c|c|c|c|c|c|c|}
\hline & Compounds & $\begin{array}{c}\text { CAS } \\
\text { number }\end{array}$ & Rt (min) & $\begin{array}{c}\text { Exact molecular } \\
\text { mass }\end{array}$ & Molecular formula & Ion formula & $M^{+}, M+2$ & Neutral mass \\
\hline 70 & Metolachlor & $51218-42-2$ & 13.9 & 283.133907 & $\mathrm{C} 15 \mathrm{H} 22 \mathrm{CINO} 2$ & $\begin{array}{c}\mathrm{C} 11 \mathrm{H} 16 \mathrm{~N} \\
\mathrm{C} 13 \mathrm{H} 17 \mathrm{CINO} \\
\mathrm{C} 13 \mathrm{H} 17(37 \mathrm{Cl}) \mathrm{NO}\end{array}$ & $\begin{array}{l}162.127725 \\
238.099318 \\
240.096368\end{array}$ & $\begin{array}{l}162.128274 \\
238.099867 \\
240.096917\end{array}$ \\
\hline 71 & Metrafenone & 220899-03-6 & 23.8 & 408.057236 & $\mathrm{C} 19 \mathrm{H} 21 \mathrm{BrO} 5$ & $\begin{array}{c}\mathrm{C} 18 \mathrm{H} 18 \mathrm{BrO} 5 \\
\mathrm{C} 18 \mathrm{H} 18 \mathrm{BrO} 4 \\
\mathrm{C} 11 \mathrm{H} 13 \mathrm{O} 4\end{array}$ & $\begin{array}{l}393.033212 \\
377.038297 \\
209.080836\end{array}$ & $\begin{array}{l}393.033761 \\
377.038846 \\
209.081385\end{array}$ \\
\hline 72 & Molinate & $2212-67-1$ & 8.9 & 187.103086 & C9H17NOS & $\begin{array}{c}\text { C7H12NO } \\
\text { C6H12N } \\
\text { C9H17NOS }\end{array}$ & $\begin{array}{c}126.091340 \\
98.096425 \\
187.102537\end{array}$ & $\begin{array}{c}126.091889 \\
98.096974 \\
187.103086\end{array}$ \\
\hline 73 & Napropamide & $15299-99-7$ & 16.5 & 271.157229 & $\mathrm{C} 17 \mathrm{H} 21 \mathrm{NO} 2$ & $\begin{array}{c}\mathrm{C} 4 \mathrm{H} 10 \mathrm{~N} \\
\mathrm{C} 7 \mathrm{H} 14 \mathrm{NO} \\
\mathrm{C} 9 \mathrm{H} 7\end{array}$ & $\begin{array}{c}72.080775 \\
128.106990 \\
115.054226\end{array}$ & $\begin{array}{c}72.081324 \\
128.107539 \\
115.054775\end{array}$ \\
\hline 74 & Novaluron & $116714-46-6$ & 7.8 & 492.012310 & C17H9CIF8N2O4 & $\begin{array}{c}\mathrm{C} 6 \mathrm{H} 5 \mathrm{CINO} \\
\mathrm{C} 6 \mathrm{H} 5(37 \mathrm{Cl}) \mathrm{NO} \\
\mathrm{C} 9 \mathrm{H} 6 \mathrm{CIF} 6 \mathrm{NO} 2\end{array}$ & $\begin{array}{l}142.005418 \\
144.002468 \\
308.998576\end{array}$ & $\begin{array}{l}142.005967 \\
142.005967 \\
308.999125\end{array}$ \\
\hline 75 & Oxadiargyl & $39807-15-3$ & 18.2 & 340.038149 & $\mathrm{C} 15 \mathrm{H} 14 \mathrm{Cl} 2 \mathrm{~N} 2 \mathrm{O} 3$ & $\begin{array}{c}\mathrm{C} 8 \mathrm{H} 5 \mathrm{CIN} \\
\mathrm{C} 9 \mathrm{H} 5 \mathrm{Cl} 2 \mathrm{NO} \\
\mathrm{C} 8 \mathrm{H} 5 \mathrm{Cl} 2 \mathrm{~N}\end{array}$ & $\begin{array}{l}150.010503 \\
212.974271 \\
184.979356\end{array}$ & $\begin{array}{l}150.011052 \\
212.974820 \\
184.979905\end{array}$ \\
\hline 76 & Oxasulfuron & $144651-06-9$ & 12.5 & 406.094707 & $\mathrm{C} 17 \mathrm{H} 18 \mathrm{~N} 4 \mathrm{O} 6 \mathrm{~S}$ & $\begin{array}{c}\mathrm{C} 8 \mathrm{H} 12 \mathrm{NS} \\
\mathrm{C} 5 \mathrm{H} 5 \mathrm{~N} 3 \mathrm{O} 6 \\
\mathrm{C} 6 \mathrm{H} 7 \mathrm{~S}\end{array}$ & $\begin{array}{l}154.068497 \\
203.017288 \\
111.026298\end{array}$ & $\begin{array}{l}154.069046 \\
203.017837 \\
111.026847\end{array}$ \\
\hline 77 & Oxyfluorfen & $42874-03-3$ & 17.2 & 361.032871 & C15H11CIF3NO4 & $\begin{array}{c}\text { C13H7F3O2 } \\
\text { C13H6CIF3NO2 } \\
\text { C15H11CIF3NO4 }\end{array}$ & $\begin{array}{l}252.039265 \\
300.003367 \\
361.032322\end{array}$ & $\begin{array}{l}252.039814 \\
300.003916 \\
361.032871\end{array}$ \\
\hline 78 & Penflufen & $494793-67-8$ & 18.7 & 317.190340 & $\mathrm{C} 18 \mathrm{H} 24 \mathrm{FN} 30$ & $\begin{array}{c}\text { C6H6FN2O } \\
\text { C15H17FN3O } \\
\text { C18H24FN3O }\end{array}$ & $\begin{array}{l}141.045867 \\
274.135016 \\
317.189791\end{array}$ & $\begin{array}{l}141.046416 \\
274.135565 \\
317.190340\end{array}$ \\
\hline 79 & Pentachloroaniline & $527-20-8$ & 12.3 & 262.862988 & $\mathrm{C} 6 \mathrm{H} 2 \mathrm{Cl} 5 \mathrm{~N}$ & $\begin{array}{l}\mathrm{C} 6 \mathrm{H} 2 \mathrm{Cl} 5 \mathrm{~N} \\
\mathrm{C} 6 \mathrm{H} 4 \mathrm{Cl} 5 \mathrm{~N} \\
\mathrm{C} 6 \mathrm{H} 6 \mathrm{Cl} 5 \mathrm{~N}\end{array}$ & $\begin{array}{l}262.862440 \\
264.878090 \\
266.893740\end{array}$ & $\begin{array}{l}262.862988 \\
264.878639 \\
266.894289\end{array}$ \\
\hline
\end{tabular}


The database of 102 compounds including: CAS number, retention times, molecular formula and exact mass of the compounds, and the formula, neutral mass and exact ion mass of fragment ions. (Cont.)

\begin{tabular}{|c|c|c|c|c|c|c|c|c|}
\hline & Compounds & $\begin{array}{c}\text { CAS } \\
\text { number }\end{array}$ & Rt (min) & $\begin{array}{c}\text { Exact molecular } \\
\text { mass }\end{array}$ & Molecular formula & Ion formula & $M^{+}, M+2$ & Neutral mass \\
\hline 80 & Penthiopyrad & $183675-82-3$ & 18.4 & 359.127918 & C16H20F3N3OS & $\begin{array}{c}\text { C12H11F3N3OS } \\
\text { C16H20F3N3OS } \\
\text { C6H4F3N2O }\end{array}$ & $\begin{array}{l}302.056944 \\
359.127369 \\
177.027023\end{array}$ & $\begin{array}{l}302.057493 \\
359.127918 \\
177.027572\end{array}$ \\
\hline 81 & Picolinafen & $137641-05-5$ & 21.2 & 376.083490 & $\mathrm{C} 19 \mathrm{H} 12 \mathrm{~F} 4 \mathrm{~N} 2 \mathrm{O} 2$ & $\begin{array}{c}\text { C12H7F3NO } \\
\text { C19H12F4N2O2 } \\
\text { C12H8F3NO }\end{array}$ & $\begin{array}{l}238.047424 \\
376.082941 \\
239.055249\end{array}$ & $\begin{array}{l}238.047973 \\
376.083490 \\
239.055798\end{array}$ \\
\hline 82 & Picoxystrobin & $117428-22-5$ & 16.5 & 367.103143 & $\mathrm{C} 18 \mathrm{H} 16 \mathrm{~F} 3 \mathrm{NO} 4$ & $\begin{array}{c}\mathrm{C} 10 \mathrm{H} 9 \mathrm{O} \\
\mathrm{C} 17 \mathrm{H} 12 \mathrm{~F} 3 \mathrm{NO} 3 \\
\mathrm{C} 9 \mathrm{H} 7\end{array}$ & $\begin{array}{l}145.064791 \\
335.076379 \\
115.054226\end{array}$ & $\begin{array}{l}145.065340 \\
335.076928 \\
115.054775\end{array}$ \\
\hline 83 & Piperonylbutoxide & $51-03-6$ & 20.2 & 338.209325 & $\mathrm{C} 19 \mathrm{H} 30 \mathrm{O} 5$ & $\begin{array}{c}\mathrm{C} 11 \mathrm{H} 12 \mathrm{O} 2 \\
\mathrm{C} 9 \mathrm{H} 9 \mathrm{O} 2 \\
\mathrm{C} 9 \mathrm{H} 11\end{array}$ & $\begin{array}{l}176.083181 \\
149.059705 \\
119.085526\end{array}$ & $\begin{array}{l}176.083730 \\
149.060254 \\
119.086075\end{array}$ \\
\hline 84 & Pirimiphos-ethyl & $23505-41-1$ & 14.7 & 333.127602 & $\mathrm{C} 13 \mathrm{H} 24 \mathrm{~N} 3 \mathrm{O} 3 \mathrm{PS}$ & $\begin{array}{c}\text { C7H10N3S } \\
\text { C12H21N3O3PS } \\
\text { C11H19N3O3PS }\end{array}$ & $\begin{array}{l}168.058995 \\
318.103578 \\
304.087928\end{array}$ & $\begin{array}{l}168.059544 \\
318.104127 \\
304.088477\end{array}$ \\
\hline 85 & Propachlor & $1918-16-7$ & 9.5 & 211.076392 & $\mathrm{C} 11 \mathrm{H} 14 \mathrm{CINO}$ & $\begin{array}{c}\text { C8H10N } \\
\text { C11H14NO } \\
\text { C8H8CINO }\end{array}$ & $\begin{array}{l}120.080775 \\
176.106990 \\
169.028893\end{array}$ & $\begin{array}{l}120.081324 \\
176.107539 \\
169.029442\end{array}$ \\
\hline 86 & Propanil & $709-98-8$ & 12.4 & 217.006120 & $\mathrm{C} 9 \mathrm{H} 9 \mathrm{Cl} 2 \mathrm{NO}$ & $\begin{array}{c}\mathrm{C} 6 \mathrm{H} 5 \mathrm{Cl} 2 \mathrm{~N} \\
\mathrm{C} 6 \mathrm{H} 5(37 \mathrm{Cl}) \mathrm{CIN} \\
\mathrm{C} 9 \mathrm{H} 9 \mathrm{Cl} 2 \mathrm{NO}\end{array}$ & $\begin{array}{l}160.979356 \\
162.976406 \\
217.005571\end{array}$ & $\begin{array}{l}160.979905 \\
162.976955 \\
217.006120\end{array}$ \\
\hline 87 & Proquinazid & $189278-12-4$ & 20.0 & 381.965431 & $\mathrm{C} 14 \mathrm{H} 8 \mathrm{Cl} 3 \mathrm{~F} 3 \mathrm{~N} 2 \mathrm{O}$ & $\begin{array}{l}\text { C8H5IN2O2 } \\
\text { C7H4INO } \\
\text { C8H3INO2 }\end{array}$ & $\begin{array}{l}287.939031 \\
244.933217 \\
271.920307\end{array}$ & $\begin{array}{l}287.939580 \\
244.933766 \\
271.920856\end{array}$ \\
\hline 88 & Pyraclofos & $89784-60-1$ & 23.7 & 360.046431 & $\mathrm{C} 14 \mathrm{H} 18 \mathrm{CIN} 2 \mathrm{O} 3 \mathrm{PS}$ & $\begin{array}{c}\text { C9H7CIN2O } \\
\text { H2O2PS } \\
\text { C14H18CIN2O3PS }\end{array}$ & $\begin{array}{c}194.024142 \\
96.950766 \\
360.045882\end{array}$ & $\begin{array}{c}194.024691 \\
96.951315 \\
360.046431\end{array}$ \\
\hline 89 & Pyridalyl & $179101-81-6$ & 26.8 & 488.967990 & $\mathrm{C} 18 \mathrm{H} 14 \mathrm{Cl} 4 \mathrm{~F} 3 \mathrm{NO} 3$ & $\begin{array}{l}\text { C9H9F3NO } \\
\mathrm{C} 3 \mathrm{H} 3 \mathrm{Cl} 2 \\
\mathrm{C} 6 \mathrm{H} 5 \mathrm{~F} 3 \mathrm{NO}\end{array}$ & $\begin{array}{l}204.063074 \\
108.960632 \\
164.031774\end{array}$ & $\begin{array}{l}204.063623 \\
108.961181 \\
164.032323\end{array}$ \\
\hline
\end{tabular}


The database of 102 compounds including: CAS number, retention times, molecular formula and exact mass of the compounds, and the formula, neutral mass and exact ion mass of fragment ions. (Cont.)

\begin{tabular}{|c|c|c|c|c|c|c|c|c|}
\hline & Compounds & $\begin{array}{c}\text { CAS } \\
\text { number }\end{array}$ & Rt (min) & $\begin{array}{c}\text { Exact molecular } \\
\text { mass }\end{array}$ & Molecular formula & Ion formula & $M^{+}, M+2$ & Neutral mass \\
\hline 90 & Quinalphos & $13593-03-8$ & 15.3 & 298.054103 & $\mathrm{C} 12 \mathrm{H} 15 \mathrm{~N} 2 \mathrm{O} 3 \mathrm{PS}$ & $\begin{array}{l}\mathrm{C} 8 \mathrm{H} 6 \mathrm{~N} 2 \mathrm{O} \\
\mathrm{C} 10 \mathrm{H} 8 \mathrm{~N} 2 \\
\mathrm{C} 10 \mathrm{H} 9 \mathrm{~N} 2\end{array}$ & $\begin{array}{l}146.047464 \\
156.068199 \\
157.076024\end{array}$ & $\begin{array}{l}146.048013 \\
156.068748 \\
157.076573\end{array}$ \\
\hline 91 & Quintozene & $82-68-8$ & 11.3 & 292.837169 & $\mathrm{C} 6 \mathrm{Cl} 5 \mathrm{NO} 2$ & $\begin{array}{l}\mathrm{C} 5 \mathrm{Cl} 5 \\
\mathrm{C} 6 \mathrm{Cl} 4 \\
\mathrm{C} 6 \mathrm{Cl} 5\end{array}$ & $\begin{array}{l}234.843716 \\
211.874851 \\
246.843716\end{array}$ & $\begin{array}{l}234.844265 \\
211.875400 \\
246.844265\end{array}$ \\
\hline 92 & Siafluofen & $105024-66-6$ & 27.0 & 408.192086 & $\mathrm{C} 25 \mathrm{H} 29 \mathrm{FO} 2 \mathrm{Si}$ & $\begin{array}{l}\text { C10H15OSi } \\
\text { C15H15FOSi } \\
\text { C17H19FOSi }\end{array}$ & $\begin{array}{l}179.088669 \\
258.087072 \\
286.118372\end{array}$ & $\begin{array}{l}179.089218 \\
258.087621 \\
286.118921\end{array}$ \\
\hline 93 & Spiromesifen & $283594-90-1$ & 20.7 & 370.214410 & $\mathrm{C} 23 \mathrm{H} 30 \mathrm{O} 4$ & $\begin{array}{l}\mathrm{C} 17 \mathrm{H} 20 \mathrm{O} 3 \\
\mathrm{C} 17 \mathrm{H} 18 \mathrm{O} 2 \\
\mathrm{C} 17 \mathrm{H} 21 \mathrm{O} 3\end{array}$ & $\begin{array}{l}272.140700 \\
254.130130 \\
273.148520\end{array}$ & $\begin{array}{l}272.141245 \\
254.130679 \\
273.149070\end{array}$ \\
\hline 94 & Sulfotep & $3689-24-5$ & 10.2 & 322.022740 & $\mathrm{C} 8 \mathrm{H} 2005 \mathrm{P} 2 \mathrm{~S} 2$ & $\begin{array}{c}\mathrm{C} 8 \mathrm{H} 20 \mathrm{O} 5 \mathrm{P} 2 \mathrm{~S} 2 \\
\mathrm{C} 4 \mathrm{H} 11 \mathrm{O} 3 \mathrm{PS} 2 \\
\mathrm{C} 2 \mathrm{H} 8 \mathrm{O} 5 \mathrm{P} 2 \mathrm{~S} 2\end{array}$ & $\begin{array}{l}322.022196 \\
201.988178 \\
237.928296\end{array}$ & $\begin{array}{l}322.022745 \\
201.988727 \\
237.928845\end{array}$ \\
\hline 95 & Terbuthylazine & $5915-41-3$ & 11.2 & 229.109423 & C9H16CIN5 & $\begin{array}{c}\text { C8H13CIN5 } \\
\text { C5H8CIN5 } \\
\text { C5H8N5 }\end{array}$ & $\begin{array}{l}214.085399 \\
173.046274 \\
138.077421\end{array}$ & $\begin{array}{l}214.085948 \\
173.046823 \\
138.077970\end{array}$ \\
\hline 96 & Tetrachlorvinphos & $22248-79-9$ & 16.1 & 363.899260 & $\mathrm{C} 10 \mathrm{H} 9 \mathrm{Cl} 4 \mathrm{O} 4 \mathrm{P}$ & $\begin{array}{c}\mathrm{C} 10 \mathrm{H} 9 \mathrm{Cl} 3 \mathrm{O} 4 \mathrm{P} \\
\mathrm{C} 2 \mathrm{H} 6 \mathrm{O} 3 \mathrm{P} \\
\mathrm{C} 10 \mathrm{H} 9 \mathrm{Cl} 4 \mathrm{O} 4\end{array}$ & $\begin{array}{l}328.929858 \\
109.004909 \\
332.924948\end{array}$ & $\begin{array}{l}328.930407 \\
109.005458 \\
332.925497\end{array}$ \\
\hline 97 & Tetrasul & $2227-13-6$ & 18.5 & 321.894434 & $\mathrm{C} 12 \mathrm{H} 6 \mathrm{Cl} 4 \mathrm{~S}$ & $\begin{array}{c}\mathrm{C} 12 \mathrm{H} 6 \mathrm{Cl} 2 \mathrm{~S} \\
\mathrm{C} 12 \mathrm{H} 6(37 \mathrm{Cl}) \mathrm{ClS} \\
\mathrm{C} 12 \mathrm{H} 6(37 \mathrm{Cl}) \mathrm{Cl} 3 \mathrm{~S}\end{array}$ & $\begin{array}{l}251.956179 \\
253.953229 \\
323.890935\end{array}$ & $\begin{array}{l}251.956728 \\
253.953778 \\
323.891484\end{array}$ \\
\hline 98 & Thiobencarb & $28249-77-6$ & 13.7 & 257.064114 & C12H16CINOS & $\begin{array}{c}\mathrm{C} 5 \mathrm{H} 10 \mathrm{NO} \\
\mathrm{C} 3 \mathrm{H} 6 \mathrm{NO} \\
\mathrm{C} 7 \mathrm{H} 6 \mathrm{Cl}\end{array}$ & $\begin{array}{c}100.075690 \\
72.044390 \\
125.015254\end{array}$ & $\begin{array}{c}100.076239 \\
72.044939 \\
125.015803\end{array}$ \\
\hline 99 & Tralkoxydim & $87820-88-0$ & 22.8 & 329.199094 & $\mathrm{C} 2 \mathrm{OH} 27 \mathrm{NO} 3$ & $\begin{array}{c}\text { C7H7NO2 } \\
\text { C6H7NO } \\
\text { C18H21NO2 }\end{array}$ & $\begin{array}{l}137.047130 \\
109.052215 \\
283.156680\end{array}$ & $\begin{array}{l}137.047679 \\
109.052764 \\
283.157229\end{array}$ \\
\hline
\end{tabular}


Hakme, E.; Herrmann, S. S.; Poulsen, M. E.

The database of 102 compounds including: CAS number, retention times, molecular formula and exact mass of the compounds, and the formula, neutral mass and exact ion mass of fragment ions. (Cont.)

\begin{tabular}{|c|c|c|c|c|c|c|c|c|}
\hline & Compounds & $\begin{array}{c}\text { CAS } \\
\text { number }\end{array}$ & Rt (min) & $\begin{array}{c}\text { Exact molecular } \\
\text { mass }\end{array}$ & Molecular formula & Ion formula & $M^{+}, M+2$ & Neutral mass \\
\hline 100 & Tralomethrin & $66841-25-6$ & 29.0 & 660.809838 & $\mathrm{C} 22 \mathrm{H} 19 \mathrm{Br} 4 \mathrm{NO} 3$ & $\begin{array}{c}\mathrm{C} 13 \mathrm{H} 90 \\
\mathrm{C} 7 \mathrm{H} 9 \mathrm{Br} 2 \\
\mathrm{C} 6 \mathrm{H} 9 \mathrm{Br} 2 \mathrm{O}\end{array}$ & $\begin{array}{l}181.064791 \\
250.906548 \\
254.901462\end{array}$ & $\begin{array}{l}181.065340 \\
250.907097 \\
254.902011\end{array}$ \\
\hline 101 & Trichloronate & $327-98-0$ & 14.4 & 331.936124 & $\mathrm{C} 10 \mathrm{H} 12 \mathrm{Cl} 3 \mathrm{O} 2 \mathrm{PS}$ & $\begin{array}{c}\text { C2H6OPS } \\
\mathrm{C} 8 \mathrm{H} 8 \mathrm{Cl} 2 \mathrm{O} 2 \mathrm{PS} \\
\mathrm{C} 10 \mathrm{H} 12 \mathrm{Cl} 2 \mathrm{O} 2 \mathrm{PS}\end{array}$ & $\begin{array}{l}108.987151 \\
268.935422 \\
296.966722\end{array}$ & $\begin{array}{l}108.987700 \\
268.935971 \\
296.967271\end{array}$ \\
\hline 102 & Triflumizole & $68694-11-1$ & 15.6 & 345.085574 & C15H15ClF3N3O & $\begin{array}{c}\mathrm{C} 8 \mathrm{H} 4 \mathrm{CIF} 3 \mathrm{~N} \\
\mathrm{C} 7 \mathrm{H} 3 \mathrm{CIF} 3 \\
\mathrm{C} 12 \mathrm{H} 12 \mathrm{CIF} 3 \mathrm{NO}\end{array}$ & $\begin{array}{l}205.997887 \\
178.986988 \\
278.055402\end{array}$ & $\begin{array}{l}205.998436 \\
178.987537 \\
278.055951\end{array}$ \\
\hline
\end{tabular}

